Mirjana Vojvoda

UDK: 737.1.032.044(37)"-00"

Archaeological Institute, Belgrade

ID: 195913996

mirjana@drenik.net

Milica Tapavički-Ilić

Archaeological Institute, Belgrade

Original research article

Received: July 05, 2011

Accepted: September 05, 2011

\title{
INHERITING THE THRONE DURING THE PRINCIPATE IN THE LIGHT OF REVERSE IMAGES ON ROMAN IMPERIAL COINS
}

\begin{abstract}
During the Principate, there were no rules regarding inheriting the throne. The principle of sons inheriting the throne from their fathers was not very successful, leading mostly to civil wars and murders. Adoption, which was continuously conducted from the time of Nerva to Marc Aurel, turned out to be a better solution. In any case, this question played an important role in the political ambitions of most of the emperors and in accordance with this, it represented a part of imperial propaganda at all levels. Motifs on coins represented one of the segments of such propaganda and supported the popularisation of the chosen heir in order to secure a peaceful transition on the throne.
\end{abstract}

\section{KEY WORDS: PRINCIPATE, INHERITING, REVERSE IMAGES, PRINCEPS IUVENTUTIS.}

The transformation of the Roman state from a republic to an empire was already being prepared during the $1^{\text {st }}$ century $\mathrm{BC}$ and took place under Augustus, by establishing the Principate. Whilst displaying great leadership skills and establishing political and military goals during the civil war, Octavian wisely created and established a new state regulation. The regime was actually placed in the hands of the first man of the state, who united the imperium, and had supreme command over the army and a number of magistrates, through whom the law was applied. ${ }^{1}$ The Sen-

1. Octavian incorporated both the tribunal and the consular ate still existed and kept some of its formal duties until the end of the empire, one of which was confirming the election of a new princeps. Augustus therefore found a solution to a new situation within the framework of the existing institutions. In connection to this, a solution had to be found to the question of inheriting the throne, which, unlike all other questions, was not compatible with the old framework. It showed that, for this delicate problem, it was not easy to apply strict rules. At-

rule, in a special way, as a sort of personal privilege, while magistrates were still elected each year. Apart from that, he was also entitled pontifex maximus.

* The article results from the project: IRS - Viminacium, Roman city and military legion camp - research of material and non material culture of inhabitants by using the modern technologies of remote detection, geophysics, GIS, digitalisation and $3 D$ visualisation (no 47018), funded by Ministry of Education, Science and Technological Development of the Republic of Serbia. 
tempts by several of the principes to seek a legal solution for naming their heirs mostly took one of two paths: a selection among family members or adoption. Bad choices invariably lead to civil wars and a greater involvement of the army in the election of the princeps, which during the $3^{\text {rd }}$ century, after the Severus dynasty, became a rule.

Octavian tried to introduce an inheritance principle among family members thereby creating a dynasty. Actually, at the beginning of his rule, he himself appeared as Caesar's heir, which was always stated in his official titular rank (Caesar divi filius), indicating the right of inheritance. In his dynastic politics, many changes happened between his direct relatives and Livia's children. After a number of tragic events and the early deaths of some of his family members (Marcel, Gaius, Lucius) Octavian had no other solution than to adopt Tiberius, making him his heir (Suet. Aug. 64,65). Later rulers of the Iulian-Claudian dynasty relied mostly upon the army, which acquired a leading role in electing the emperor. The most important role was played by the praetorians and not by the army as a whole. Their selection was approved by provincial legions, which turned into a sort of dictatorship and imposed the election of the praetorians. Claudius introduced financial support to the praetorians for their services connected to his investiture (Suet. Claud. 10). ${ }^{2}$ By leading a scandalous private life, Nero completely neglected his connections to the army, which again led to certain political ambitions of some of the generals, who were already familiar with rivalries among different parts of the Roman army. All of this led to riots, initially in Gaul, Spain and Numidia, which escalated to civil war. It turned out that provincial armies were able to impose their will on the election of principes.

Vespasianus from the Flavian dynasty won the civil war, although without any famous ancestors or military leaders in his family. By that time,

2 Claudius was the first emperor who paid the praetorians for their support in his election. in Roman society, the idea of inheriting the throne within one family was already quite accepted, although for the election of a new princeps, a major role was played by officers and provincial legions (Tacitus Hist. II.76). Vespasianus selected his sons as his heirs, first Titus, then Domitianus, who, like Augustus, attempted to establish his own dynasty. Still, dissatisfaction caused by his absolutistic reign and by his character led to a plot in which he, as the last member of this dynasty, was murdered. These and other events showed that the election of the wrong heir could lead to civil war and the destabilisation of the state. Nerva, as a member of the senatorial class, ascended the throne supported by the praetorians. Nevertheless, he was suddenly faced with strong resistance from the provincial army. He therefore adopted Traian, the governor of Upper Germania (Germaia Superior), who was very popular among the soldiers. Adoption was practised continuously during the reign of the Antonine dynasty, and proved to be a better solution. This practice was interrupted by Marc Aurel, who had no doubts about the choice of his heir and gave titles to his son Comodus at a very early age that were usually given to a co-ruler. After his father's death, Comodus was proclaimed the new princeps, even by the senate. Since Comodus possessed none of the qualities of a good ruler, his insignificant reign again ended with the murder of the princeps and civil war. After the end of the war and the establishment of the Severan dynasty, it turned out that provincial legions again played a more important role in choosing the princeps than the senate and the praetorians. The elevated role of the army during the Severan reign led to the absolute dependence of the state on the decisions of the soldiers and later on the rule of the so-called solder-emperor, which lasted until the end of the Principate. After the death of Alexander Severus up until the beginning of Diocletian's rule, many rulers ascended to the throne. With only a few exceptions all ascended with the help of the army. Their origin was of no importance, only their abil- 
ity to stand up to foreign enemies mattered. During this time there were also attempts to establish dynasties which usually resulted in the murder of the emperor and his co-ruler son. The army became a decisive political factor in bringing their commanders to the throne, causing numerous civil wars whilst also leading to negligence in the defence of the borders, weakening the state as a whole. Instability on most of the borders along with the ever increasing cost of permanent warfare, general insecurity, a reduction in trade and production and riots led the state into anarchy. It was clear that the Principate, established by Augustus, was in crisis during the second half of the $3^{\text {rd }}$ century and that it was necessary to transform the system of state leadership. The old-fashioned system of the Principate was replaced by a tetrarchy under the reign of Diocletian.

Dynastic politics during the Principate represents an important segment of the coinage based official propaganda. The basic way was to give the title of princeps iuventutis to a chosen candidate by the current princeps. This title had been respected since republican times, and was given to a young man intended to lead younger and older boys chosen to play roles in the Trojan play (ad ludum Troiae). In the republic, the princeps iuventutis was the leader of the cavalry and his major features were a spear and a silver shield (Stevenson 1964: 652). Ever since Augustus's time, this title was given to younger male members of the imperial family, destined to be future heirs to the throne. Princeps iuventutis was given a silver shield and a spear, while images on coins adequately depicted this important act in the life of a future ruler. Ever since their youth, principes were prepared and educated for the role which was expected of them which included important state and military functions. Different images on coins accompanied the inscription PRINCEPS IVVENTVTIS, all aimed at introducing the future heir to the people and the army, and to represent him as a qualified and capable ruler.
During almost his entire rule, Octavian looked for an appropriate heir. ${ }^{3}$ His biggest favourites were his grandchildren Gaius and Lucius. Accordingly, he first used the title princeps iuventutis for them, describing them as heirs to the throne. First Gaius, then Lucius, was given this title in the years 5 and 2 BC (Kienast 2010: 74-75). Even before that, Octavian began to introduce Gaius to military life in order to give him the necessary experience. He accompanied Octavian and Tiberius during the Gallic campaign in $8 \mathrm{BC}$ and on the obverses of the aurei and denarii of the Lugdunum mint, Gaius was depicted on a galloping horse, holding the reins in his right hand, with a sword and shield in his left. Behind him, can be seen a legionary eagle between two military insignia, with the inscription C CAES AVGVS F (Fig. 1) (RIC Ia: 54, nos. 198,199). ${ }^{4}$ Ever since 2 BC in the same mint, aurei and denarii were minted on which both of the princeps are depicted, along with the inscription C L CAESARES AVGVSTI F COS DESIG PRINC IVVENT (Fig. 2) (RIC Ia: 55-56, nos. 205-212). ${ }^{5}$ Gaius and Lucius are standing, dressed in togas, with their hands placed on their shields. Behind each shield there is a spear and between the tops of these spears there

3 Since he had no sons of his own, Octavian had his daughter Iulia married three times, with the hope of getting an heir from these marriages. Alternatively, there were Livia's sons, Drusus and Tiberius, both very capable soldiers. Initially he wanted Marcelus for his heir, the son of his sister Octavia, whom he married to Iulia. Marcelus died in $23 \mathrm{BC}$, leaving no heir from his marriage to Iulia. In 21 $\mathrm{BC}$, he married Iulia to Agrippa, his old friend and fellowsoldier, and five children resulted from this relationship. In 19 BC Agrippa was included in a type of co-ruling and was given much authority. After his death in $12 \mathrm{BC}$ and the death of Drusus in $9 \mathrm{BC}$, Augustus turned his attention towards his grandsons Gaius and Lucius. He married Iulia to Tiberius, in spite of his dissatisfaction, and seven years later, he withdrew to the island of Rhodes. Gaius and Lucius were introduced into public life and it seemed that they were the most appropriate candidates for the throne. A tragedy occurred and both of the grandsons died, Lucius in $2 \mathrm{AD}$ and Gaius in $4 \mathrm{AD}$. There was no other solution left for Octavian but to adopt Tiberius, who was, on the other hand, forced to adopt Germanicus, Drusus's son.

4 Illustration taken from BMC I, Pl. 12.15.

5 Illustration taken from BMC I, Pl. 13.9. 
is a simplum and a lituus. The simplum stands next to Gaius as a sign of his pontificate, while the lituus stands next to Lucius, as a symbol of his augurate. ${ }^{6}$ In less frequent series there is also an $\mathrm{X}$ under the lituus and the simplum. ${ }^{7}$

After Gaius and Lucius, the coinage entitled princeps iuventutis was minted only for Nero, who was adopted by Claudius in $50 \mathrm{AD}$ and gained his title in $51 \mathrm{AD}$ (Kienast 2010: 96). ${ }^{8}$

6 Among these series are examples on which the simplum (Gaius) was presented to the left and the lituus (Lucius) to the right, but also series on which the position is reversed: lituus (Lucius) on the left and simplum (Gaius) on the right.

7 The problem with these series lays in determining the end of their minting period. Mattingly was first of the opinion that they were minted until $11 \mathrm{AD}$ (BMC I: cxiv), later until 9 or $10 \mathrm{AD}$ (RIC I: 48), while in the revised edition RIC I Sutherland and Carson determined the end date as: "(?) $4 \mathrm{AD}$ or beyond" (RIC Ia: 28,55 , ref. *). Grant thinks that they were minted even after Augustus's death, which is less possible, because both of Octavian's grandsons died before him, Lucius in $2 \mathrm{BC}$ and Gaius in $4 \mathrm{AD}$ (Grant 1954: 79). While dealing with this problem and by relying on the great number of samples of the series without the $\mathrm{X}$ beneath the lituus and simplum, Macdonald realised that, without exception, Gaius's shield overlaps Lucius's shield (in addition, each prince is depicted with his priestly symbols either on the left or on the right). We can conclude from this that the protocol was being followed that states the superior position of Gaius as the older brother of Lucius. Macdonald noticed that the examples with the $\mathrm{X}$ do not follow this rule, which, according to him, is important for the dating of the series. According to him, on the examples with the $\mathrm{X}$ it was no longer important to state the privileged position of Gaius and therefore, these series were minted after his death, at some time between 4 and $13 \mathrm{AD}$. The series without the $\mathrm{X}$ were minted between $2 \mathrm{BC}$ and $4 \mathrm{AD}$. He understands the $\mathrm{X}$ to be a control mark denoting later minting (Macdonald 1979: 28-29).

8 In June 4 AD at Augustus's persistence, Tiberius adopted Germanicus, who was proclaimed a caesar. It is not clear whether Germanicus was also given the title of princeps iuventutis on the same occasion (Kienast 2010: 80). At the same time, Tiberius's son Drusus was proclaimed a caesar. The enthroning of Tiberius was not under suspicion and the senators were only expected to agree, as it had already been arranged while Octavian was still alive. After the suspicious death of Germanicus in $19 \mathrm{AD}$ and that of Drusus in $23 \mathrm{AD}$, Tiberius retired to the island of Capri. Shortly before his death, he considered as heirs Germanicus's son Gaius Caligula, as well as his grandson Tiberius Gamel, Drusus's son. Gamel was closer to his heart, but still under age, while Caligula was at the peak of his strength and was well favoured among the people and soldiers (Tac.
Claudius minted aurei and denarii for Nero, with the inscription EQVESTER ORDO PRINCIPI IVVENT written in four lines on a shield, under which there was a spear (Fig. 3) (RIC Ia: 125, nos. 78,79$).{ }^{9}$ In addition, there was a coin with a bust of the young Nero and the inscription NERO CLAVD CAES DRVSVS GERM PRINC IVVENT (Fig. 4) (RIC Ia: 126, nos. 82, 83). ${ }^{10}$

Numerous variations, promoting the politics of the dynasty, were minted by Vespasianus for his sons, in particular Domitianus, but also later by Titus, for his younger brother. From the beginning of his rule Vespasianus left nobody in any doubt that he intended to establish a dynasty which, according to Suetionius, he also stated in front of the senate (Suet. Vesp. 25). As well as the images entitled princeps iuventutis, there were others aimed at presenting the future heirs to the public. Along with the legends CAESAR AVG F COS CAESAR AVG F PR (Fig. 5), ${ }^{11}$ CAE DOM ET T CAES IMP VESPAS and LIBERI IMP AVG VESPAS busts of Titus and Domitianus were depicted, facing each other (RIC II: 48, n. 283; 61, n. 386 ; 57, nos. 358,359 ; 52-54, nos. 313-315, 321, $322,330,331)$. On a sestertius with the inscription T ET DOM C EX S C, from the year $70 \mathrm{AD}$, the principes were depicted as magistrates, each sitting on his own platform, facing each other, with two figures between them wearing togas (Fig. 6) (RIC II: 64, n. 404). ${ }^{12}$ The abbreviation $\mathrm{C}$ suggests that they are caesars and not consuls. Titus already possessed a consulate, while Domitianus

Ann. VI.52). After Tiberius's death, with the help of the praetorians and the Senate, Caligula was proclaimed a new princeps. He very quickly got rid of Tiberius Gamel. After Caligula's murder there was turmoil. The praetorians brought Claudius into their camp, while the consuls, helped by the city cohorts, took the Capitoline Hill and the Forum, intending to establish the republic again. However, the Senate was insecure and people gathered to ask for the rule of only one man, suggesting Claudius's name. The soldiers swore allegiance to him and Claudius promised 15,000 sestertii to each of them (Suet. Claud. 10).

9 Illustration taken from BMC I, P1. 33.10.

10 Illustration taken from BMC I, P1. 33.4.

11 Illustration taken from BMC II, P1. 15.8.

12 Illustration taken from BMC II, Pl. 31.9. 
was a praetor during the same year. In this way, homage to Domitianus was indirectly paid, showing him equal with his older brother (BMC II: lvi). During the same year, sestertii were minted with depictions of Titus and Domitianus in military uniforms, facing each other. Domitianus stands on the right side, holding a spear and a parasonium, while Titus stands on the left side, holding a spear and a scroll (Fig. 7) (RIC II: 66-67, nos. 413-415; 101, n. 738). ${ }^{13}$ Domitianus is shown as princeps iuventutis with a spear and a parasonium, while Titus, shown as emperor, holds a spear and a scroll as symbols of public life. The inscription on these examples is CAES AVG F DES IMP AVG F COS DES IT S C, showing that Titus was proclaimed an emperor, ${ }^{14}$ while Domitianus obviously received the second consulate. This presents a problem, because Domitianus did not receive the COS II until 73 AD. ${ }^{15}$ It was most likely that Vespasianus tried to reduce the gap between the brothers, just like on the previously described example, thus showing a certain sympathy and understanding towards his younger son. ${ }^{16}$ On denarii minted in 71/72 AD, Titus and Domitianus are shown facing each other and holding shields, with the inscription VESPASIANI AVGVSTI FILI DOM ET T (RIC II: 33, n. 152).

Titus and Domitian officially gained the titles princeps iuventutis in December $69 \mathrm{AD}$ (Kienast 2010: 111, 115). Depictions on the reverse show them together, with the inscription $\mathrm{T}$ ET DOMIT CAESARES PRINC IVVEN in three different motifs: on horses galloping to the right, each holding a spear in his right hand, with an infantry soldier in front of them, carrying a vexillum (Fig. 8) (RIC II: 62, n. 390); ${ }^{17}$ on horses galloping

13 Illustration taken from BMC II, Pl. 20.1.

14 Titus was entitled IMP on the 6th of August (?) $70 \mathrm{AD}$; cf. Kienast 2010: 112.

15 Domitianus was entitled COS II between the 1st of January and the end of February (?) 73 AD (Kienast 2010: 116).

16 Domitianus was openly against Titus, information given by Suetonius (Suet. Titus 9, Domit. 2).

17 Illustration taken from BMC II, Pl. 42.7. to the right, wearing military uniforms and each holding a spear in his right hand (Fig. 9) (RIC II: 49, n. 292) $;^{18}$ dressed in togas, sitting on curile chairs, one next to the other, with each holding a branch in his right hand (Fig. 10) (RIC II: 17-18, nos. 23-27; 49, n. 293). ${ }^{19}$

After $71 \mathrm{AD}$, Titus no longer appears in this role and the depictions with the inscription princeps iuventutis were minted for Domitianus only. No matter whether obverses bear the portrait of Vespasiaus or Domitianus, on bronze coins a princeps wearing a military uniform is depicted, galloping and holding a spear (RIC II: 80, n. 536; 82, n. 579) or a sceptre (RIC II: 97, n. 697; 98, n. $711 ; 100$, n. 728) with the inscription PRINCIP IVVENT (Fig. 11). ${ }^{20}$ Apart from this image, on gold and silver coins there were a greater number of different images which were not usually combined with the inscription PRINCEPS IVVENTVTIS and as such, they represent exceptions in the minting of the Principate era. On aurei and denarii minted between $74 \mathrm{AD}$ and $79 \mathrm{AD}$, the following images were represented: Spes walking, whilst holding a flower and hitching her dress (Fig. 12) (RIC II: 41, n. 233; 60, n. 380);21 Salus standing, leaning on a pillar and feeding a snake from a patera (Fig. 13) (RIC II: 42, n. 239; 43, n. 243); ${ }^{22}$ Vesta sitting and holding a paladium and a sceptre (Fig. 14) (RIC II: 43, n. 244);23 a goat standing in a laurel wreath (RIC II: 43, n. 245); clasped hands holding an eagle on the bow of a ship (Fig. 15) (RIC II: 43, n. 246). ${ }^{24}$ During his independent reign, Titus minted some of the aforementioned motifs for Domitianus (Salus, Vesta, goat in a laureal wreath (Fig. 16), ${ }^{25}$ clasped hands), but there were also some new motifs: Pax sitting, an

18 Illustration taken from BMC II, Pl. 13.15. 19 Illustration taken from BMC II, Pl. 13.11. 20 Illustration taken from BMC II, Pl. 27.12. 21 Illustration taken from BMC II, Pl. 4.15. 22 Illustration taken from BMC II, P1. 8.5. 23 Illustration taken from BMC II, Pl. 8.3. 24 Illustration taken from BMC II, Pl. 8.7. 25 Illustration taken from BMC II, Pl. 46.9. 
adorant person next to her feet (RIC II: 121, n. 39); Minerva walking, waving a spear and holding a shield (Fig. 17) (RIC II: 121, n. 41); Aries on a globe (RIC II: 121, n. 44); an altar with a flame decorated with garlands (Fig. 18) (RIC II: 121, n. $46 ; 122$, n. 50); a Corinthian helmet on a throne (Fig. 19) (RIC II: 121, n. 47; 122, n. 51).

These exceptions from the usual images, accompanied by the inscription princeps iuventutis on the Principate coinage demand further explanation. Spes represents hope, an idea of restitution and youth, and this is why during the Empire, along with Iuventus, she was connected to emperors. ${ }^{26}$ As Spes populi Romani she represents the hope of future generations and as Spes Augusta she is symbolises the progress of the emperor and his heir son or sons, and is closely connected to Salus and Fortuna (OCD: 1009). Salus represents welfare in a very broad sense, connected to Fortuna and Spes. As Salus publica populi Romani during the Empire, she was first replaced with Salus Augusta, and as such, the idea of general welfare was connected to a single person, the emperor. The joined concepts of Salus and Spes, especially during the Principate, represented protectors of the emperor and his family, especially after a heir was born (Clark 1983: 82). The Salus cult developed and followed social changes, starting to mark general and public security and the defensive strength of the independent state against all kinds of dangers, both inner and outer (Ranieri 2001: 177). ${ }^{27}$ Pax represents the personi-

26 During the first Punic war, A.A. Calatin, who was a consul in 258 and $254 \mathrm{BC}$, erected a temple to Spes in honour of the victory over Carthago. The temple burned twice and was rebuilt by Germanicus in 17 AD (Tac. Ann. II.49). The connection between Spes and Iuventas is particularly emphasised during the early Principate. The day when Augustus was given the toga virilis, on the 18th of October, was marked as supplicatio Spei et Iuventuti. This can also be understood as a glorification of the charismatic young Augustus, as well as a declaration of his future virtues (Clark 1983: 82). On coins, it appeared for the first time during the time of Claudius, after his son and heir Britannicus was born in 41 AD (BMC I: clvi).

27 Salus is one of the old Roman deities, respected along with Semo Sancus Dius Fidius before the building of the fication of peace and welfare, brought about by peace itself. In the beginning, she was more a personification of inner concordance - a term barely different from Concordia. In this sense, she also represents a protector from the dangers of civil wars (RE, Bd. XVIII-4: 2430.30-38). Her cult became especially significant after the consecration of the Ara Pacis Augustae on Mars'es field in 9 BC. A year earlier, Augustus placed statues of Pax, Concordia and Salus, to which each year in March, public sacrifices were offered. ${ }^{28}$ Another important monument dedicated to Pax is the Flavian temple, consecrated in 75 AD (Dio Cass. LXVI.15), through which Vespasianus depicted him as a peace-maker, attributing numerous propaganda allusions to the time of Augustus. ${ }^{29}$ Vesta

temple on the Quirinal in $302 \mathrm{BC}$ which was dedicated by the dictator Bubulcus (RE Bd. I.A.2: 2057.30-43; LIMC VII: 661). From the beginning of the 2 nd century BC, Salus was made equal to Hygieia and each year, after studying the Sibyllian books, offers were made to Apollo, Aesculapes and Salus. Hygieia gave no other features to Salus but the iconographical ones, so Salus was respected as the goddess of the welfare of the state (RE Bd. I.A.2: 2058.5059; 2059.10-20). From the time of Augustus, she was respected together with Pax and Concordia, to whom statues were erected by Augustus in 10 BC. On the imperial coins they appear for the first time on Nero's minting, after he was saved from Pisos' plot. Nero also built a temple for Salus at this time (Tac. Ann. XV.74).

28 In Augustus' propaganda, Pax was represented as the strongest symbol of the imperial rule and was respected as a deity, protecting the state and the emperor. This was, of course, understandable in times when everybody was yearning for peace after a long lasting bloody civil war (RE, Bd. XVIII-4: 2430.63-69; OCD: 793).

29 Vespasianus introduced several of the new Pax types into his minting. There is an interesting motif of Pax standing, holding a winged caduceus above the altar on which there is a sachet (follis), in her left hand there is a branch and she is leaning on a column (RIC II: 20, n. 47). In this picture, Pax holds her attribute, an olive branch, as well as a caduceus Felicitas and she is leaning on a column, the symbol of Securitas. The propaganda message was that peace, introduced by Vespasianus, brings welfare and security in all segments of society. The other interesting example in Vespasianus' minting is an image of Pax holding a branch and a torch with which she sets a pile of weapons on fire; behind her there is a column with Minerva's statue, a shield is leant against the column and there is the inscription PAX AVGVSTI (RIC II: 68, n. 434). In this picture, Pax does not only mean that peace is accomplished, she becomes the virtue of the emperor 
was an ancient Roman goddess of homely fire, although her role in the official cult was much more important. In her temple, there was a public fire and the cult was taken care of by a pontifex maximus (the emperor himself during the time of the Empire) and the vestals. This is why, ever since the beginning of the Empire, it was closely connected to the imperial family, especially the emperor's wife. Domitianus considered Minerva his protectress and offered her the greatest honours (Dio Cass. LXI.1.2; Suet. Domit. 15). Minerva's images are numerous during the period of Domitianus' independent minting, so it is little wonder that she appeared even earlier, bearing with the title princeps iuventutis. Clasped hands holding an aquila represent a common iconographical motif accompanied by the legends fides militum/exercituum or concordia militum/exercituum in the sense of concordia or loyalty to the emperor and the army (Arsenijević 2006: 84-86, 98-100). The example of Domitian's type with the inscription princeps iuventutis minted in 79 and $80 \mathrm{AD}$, most likely alluded to concordia within the army, confirming Suetonius' words that Domitian thought of offering a reward of double money to any soldiers who supported him against his brother (Suet. Domit. 2). The goat in the laurel wreath represents Amalteia, Zeus' nurse. The legend of Amalteia was used here as mass propaganda showing great sympathy towards the young princeps, destined to be the heir. The role of Jupiter's representative on earth is emphasised, under whose reign the world is being restituted in a new golden age of peace and prosperity (Fears 1981: 79; Preimesberger 2011: 63). ${ }^{30}$ The Corinthian helmet on a throne and the altar in flames belongs to the group of pulvinaria types; the helmet for Minerva and the altar

himself, her special form, through which he becomes a peace-maker (BMC II: xlvii).

30 A similar propaganda idea was also developed later, during the time of Valerius II, with the inscription IOVI CRESCENTI and the image of a boy-Jupiter riding Amalteia (RIC V.1: 116, n. 1). for Vesta. ${ }^{31}$ The Aries on a globe is an alternative depiction of Octavianus, whose horoscope sign was Aries. It was first minted by Vespasianus and later by Titus, in an attempt to connect themselves to Octavian.

As shown, Spes and Salus can be connected to the princeps, although they do not represent common types with the inscription princeps iuventutis. Pax and Aries evoke Octavian's time and the time of improved welfare after the years of civil war and suffering. Vespasianus wanted to stress the same idea, putting himself in the main role - a peace-maker, who saved the people and the state and, like Octavian, restored order. The motif of the goat Amalteia, the nurse of the young Jupiter, carries the idea of renovatio temporum through growing and educating the youth. Moreover, the idea of a direct connection between Jupiter and Domitianus should not be excluded. The examples with clasped hands were most likely minted after Vespasianus' death, testifying to a discordance among the brothers which was, according to sources, caused by Domitianus (Suet. Titus 9; Domit. 2).

After Domitianus' murder and the proclamation of Nerva as the new emperor by the senate, the army was dissatisfied with this choice and as a result, Nerva adopted Traian in 97 AD. From the time of Traian's adoption in October $97 \mathrm{AD}$ until Nerva's death in January 98 AD, no coins were minted which would indicate the position of the new heir. Nevertheless, during his first year of independent reign, Traian minted aurei and denarii with an image in which he was depicted receiving the globe from Nerva (Fig. 20) (RIC II: 246, n. 28). ${ }^{32}$ The accompanying inscription of PROVID indicates Nerva's wisdom in choosing the correct

31 The main reasons for minting the whole series of pulvinaria types during the reign of Titus were the three major catastrophes which occurred in $79 \mathrm{AD}$ and $80 \mathrm{AD}$ - the Vesuvius eruption, the great plague and a fire in Rome (Suet. Titus 8; Dio Cass. LXVI.21.1; BMC I: 1xxii-lxxiii). 32 Illustration taken from BMC III, P1. 10.3. 
heir. ${ }^{33}$ This idea was especially developed during the time of Traian and Hadrianus, not just as providentia augusti, but also as providentia deorum in connection with Jupiter. ${ }^{34}$ In addition, Traian also minted aurei with the busts of Nerva and Traian the Elder facing each other, with the inscription DIVI NERVA ET TRAIANVS PAT/ER (Fig. 21) (RIC II: 297, nos. 726, 727). ${ }^{35}$ In this way, Traian paid homage to his ancestors, to his biological father and to Nerva, who adopted him.

It was obvious that Traian held Hadrianus's military capability in high regard, since he left him commanding the greatest army in the east before he left for Rome, most likely on the $4^{\text {th }}$ of August 117 AD. ${ }^{36}$ Still, he never officially proclaimed Hadrian as his heir, the reasons for which remain unknown. Traian became seriously ill and he died on the road several days later. After receiving the notice about his death, the army of Syria proclaimed Hadrian as the new emperor (CAH XI: 299-300). Since it was only after this

33 It was known that Nerva's life was under permanent threat. He was especially endangered by the praetorians, who were dissatisfied with the murder of Domitianus (Dio Cass. LXVIII.3, 4). One of the reasons for adopting Traian, apart from his proven military capability, was his great popularity among the soldiers. However, Traian reached the throne not through a civil war, but peacefully, through adoption.

34 Providentia augusti referred to the emperor's care in a broad sense, from the choosing of the heir to supplying the citizens and it represents his ability to foresee everything concerning the welfare of the state and the people. The connection with Jupiter was specific. In examples in which the emperor was depicted within his thunderbolt, it shows not only under whose protection the emperor stood, but also by whom he was chosen to rule, i.e. they represented the providentia of Jupiter himself. Between 112 AD and $117 \mathrm{AD}$, Traian minted aurei, denarii and sestertii with the motif of a colossal figure of Jupiter, standing and holding a thunderbolt in his stretched arm, above him there is a significantly smaller figure of Traian who holds a branch; the inscription says CONSERVATORI PATRIS PATRIAE (RIC II: 261, n. 249; 287, n. 619). This original idea of layering the figures was later explicitely shown in scenes in which Jupiter hands the globe to the emperor. These scenes will be discussed later in the paper.

35 Illustration taken from BMC III, Pl. 17.18.

36 By becoming a Syrian legate, Hadrian received the socalled second position in the state, as he had eleven legions and a great number of auxiliary troops under his control. that the notice came to Rome that Traian had proclaimed Hadrian as his heir on his deathbed, rumours were spread through the city, similar to those spread after Octavian's death (Tacitus Ann. I.7). ${ }^{37}$ It was clear that coins soon needed to be minted, on which Hadrian would be called Augustus and an heir. Of interest is an aureus on whose obverse there is a bust of Traian in armour with a laurel wreath, and the inscription IMP CAES NER TRAIAN OPTIM AVG GERM DAC; while on the reverse there is a bust of Hadrian, also with a laurel wreath on his head and with the inscription HADRIANUSO TRAIANO CAESARI (RIC II: 338, n. 1) ${ }^{38}$ According to this, one could conclude that Hadrian was a caesar and not Augustus and that the coins were minted while Traian was still alive. It is also possible that they were minted after Traian's death, but before the notice reached Rome (RIC II: 338, ref. 1). Either way, the first of Hadrian's Augustan series refer to adoption and the inheritance of the throne. On aurei and denarii minted in $117 \mathrm{AD}$ we can see Traian depicted handing the globe to Hadrian (Fig. 22) (RIC II: 338 , n. 2) ${ }^{39}$ or Traian and Hadrian shaking hands with the inscription ADOPTIO (Fig. 23) (RIC II: 339, n. 3; 341-342, nos. 22 A-C). ${ }^{40}$ The symbolic handing over of the reign over the world, depicted as handing the globe to Hadrian, as well as the scene with the dextrarum iunctio motif, with an

37 Hadrian was Traian's cousin, under his custody since he turned ten, along with Acilius Atianus (prefectus praetoriae at the time of Traian's death). Traian brought Hadrian to Rome and treated him as his own son (SHA, Vita Hadrianusi II.2). In keeping with all others of a similar position, he started his military career from the lowest ranks, but he was very successful and accompanied Traian on all of his military campaigns. He enjoyed the support of Plotina, Traian's wife, as well as that of Acilius Atianus, the praefectus praetoriae and Dio Cassius (Dio Cass. LXIX 1.1-2). Hadrian was not adopted at all, but ascended the throne with their help. Concerning rumours about Hadrian's proclamation see cf. SHA, Vita Hadrianusi IV.8-10; Strack 1933: 42.

38 This example was once in the Paris collection, while the British Museum possesses a replica (BMC III: 124, ref. *).

39 Illustration taken from BMC III, Pl. 46.1.

40 Illustration taken from BMC III, Pl. 46.4. 
emphasised adoptio as an inscription, clearly show that inheritance was provided through providentia augusti (Traiana), by the handing over of the reign to the adopted heir. Dextrarum iunctio is a gesture of great ritual symbolism, which in the first place indicates the concept of Fides uniting the two persons depicted with an unbreakable bond, but also indicates concordance, i.e. Concordia. ${ }^{41}$

As previously mentioned, the development of the providentia deorum began under Traian and gained more direct associations during Hadrian's time. Therefore, on aurei minted between 119 AD and $122 \mathrm{AD}$, Hadrian is depicted dressed in a toga, receiving the globe from Jupiter with both hands, next to whose feet there is an eagle (Fig. 24) (RIC II: 353 , n. 109).$^{42}$ At the same time, sestertii and dupondii were minted under Hadrian, with the legend PROVIDENTIA DEORVM, on which he was depicted in a toga, looking up at an eagle who flies towards him, bearing a sceptre in its beak (Fig. 25) (RIC II: 415, n. 589; 418, n. 602). On the aurei minted at the end of his reign (134-138) Jupiter is standing, holding a sceptre and crowning Hadrian (RIC II: 369, n. 250).

Of special interest is the motif on aurei and denarii (119-122) showing Hadrian as a genius of the "golden age", standing in an oval frame, holding a symbol of permanent inheritance in his hand, a phoenix on a globe with the inscription SAEC AVR (Fig. 26) (RIC II: 356, n. 136). ${ }^{43}$ The inscription saeculum aureum, usually hidden behind phrases like felicitas temporum or saeculi felicitas, was clearly stated in this case and it represents a unique example in Roman minting (BMC III: cxxxi). In this way, Hadrian was represented as a link in the unbroken chain of the rule the world.

In $136 \mathrm{AD}$, Hadrian adopted Lucius Aelius and minted him coins until his death on the

41 Concerning the interaction of the concepts Fides and Concordia within the image of shaking hands on Roman imperial coins see cf. Arsenijević 2006: 84-86, 98-100.

42 Illustration taken from BMC III, P1. 51.8.

43 Illustration taken from BMC III, P1. 52.10. $1^{\text {st }}$ of January 138 AD (SHA, Vita Hadrianusi XXIII.10-16). None of his minted caesarian series indicate inheritance except a bronze medallion showing Hadrian and Aelius shaking hands in the presence of Concordia (Gnnechi II: 9, n. 1). Hadrian, already very ill, had to choose an heir once again. On his birthday in $138 \mathrm{AD}$, he announced that he was going to adopt Antoninus Pius, under the condition that he himself adopts Marc Aurel (engaged at the time to the daughter of the late Aelius) and Lucius Verus (Aelius' son) (SHA, Vita Hadrianusi XXIV.1). Antoninus Pius was proclaimed as a caesar and coins were also minted in his name, but without any allusions of inheriting the throne.

After Hadrian's death, Antonius Pius married Marc Aurel to his daughter Faustina the Younger and, in 139 AD, entitled him caesar and princeps iuventutis (SHA, Vita M. Aurel. VI.3; Kienast 2010: 137). Although he adopted Lucius Verus while Hadrian was still alive, Antonius Pius never gave him any of the titles that he gave to Marc Aurel. His only images on coins appeared during the reign of Antonius Pius on aurei minted between $140 \mathrm{AD}$ and143 $\mathrm{AD}$, on which they are in a quadriga steered by Antonius Pius and in front of them there are two smaller figures of adopted sons (RIC III: 37, n. 93). In the name of Marc Aurel however, coins were minted from the beginning. First, in $139 \mathrm{AD}$, there are portraits of A. Pius (obverse) and M. Aurel (reverse) (RIC III: p. 77, nos. 411-414) and in $140 \mathrm{AD}$ there was a series in all metals with the depiction of the standing Iuventas holding a patera and pouring incense over a candelabra with the inscription IVVENTAS (Fig. 27) (RIC III: 79, n. 423; 173, n. $1232 ; 174$, n. 1238). ${ }^{44}$ Sestertii and dupondii with the same inscription were minted at the same time, with an image of Iuventas holding a branch, with a trophy behind her (Fig. 28) (RIC III: 173, n. $1233 ; 174$, n. 1239). ${ }^{45}$ Somewhat later, in 145

44 Illustration taken from RIC III, P1. III.74.

45 Illustration taken from BMC IV, Pl. 33.12. 
$\mathrm{AD}$, dupondii were minted with the inscription IVVENTVS in an oak wreath (RIC III: 176-177, nos. 1261, 1262).

Instead of types with military elements, which would have been more appropriate for the princeps iuventutis motif for Marc Aurel, one sees the image of Iuventas. The personification symbolises youth in general, especially the youth of Italy, whose natural representative was Marc Aurel himself. As previously mentioned, Iuventas was connected with the younger members of the imperial family in a specially stratified form of expression. ${ }^{46}$ In the same way, the more strict military virtue, reflected in Virtus, was replaced by the less strict Honos holding a branch and a cornucopia on the caesarian series of Marc Aurel (RIC III: 17, 175, n. 1241).

Within the mintings of M. Aurel as a caesar, two images hold a special place, both alluding to his role as the representative of the youth. Both are depicted on medallions. On the first, most likely minted in $139 \mathrm{AD}$, the caesar M. Aurel is depicted on a galloping horse and holding the legionary eagle (Fig. 29) (Gnecchi III: 32, n. 106) ${ }^{47}$ The second was minted in $155 \mathrm{AD}$, with the image of Castor standing in front of a horse (Fig. 30) (Gnecchi II: 31 , n. 39) ${ }^{48}$ In cases when Castor appears in princely mintings, we can almost definitely say that it represents a direct connection with the princeps iuventutis concept. The role of Castor among the equestrian class, as their patron, is similar to that of Iuventas, who represents the eternal youth of Rome, expressed through the victorious vitality of the generations to come (LIMC III: 632).

We can conclude that such a sophisticated way of expressing the image of a caesar in the role of princeps iuventutis was carefully planned and chosen by Antonius Pius or even Marc Aurel himself.

After A. Pius' death, "The Senate forced Marc to accept the rule of the state and he selected

46 Cf. ref. 26.

47 Illustration taken from Gnecchi III, Tav. 150.8. 48 Illustration taken from Gnecchi II, Tav. 62.2. his brother as a co-ruler" (SHA, Vita Mac. VII.5). A new era begins for the Principate, a shared reign of two people with the same title. However, there is no doubt that the first princeps kept his right to make decisions on all the more important matters. After the death of Lucius Verus, the role of the subordinate ruler was taken by Comodus. ${ }^{49} \mathrm{By}$ giving Comodus rights equal to his own, M. Aurel clearly showed who the chosen heir to the throne was. In such a way, after almost a century, the tradition of adoption was broken, which would soon prove to be a bad solution. ${ }^{50}$

With regard to the concept of the scenes chosen, the coins with the princeps iuventutis motifs, minted during the time of Comodus, very much resemble the series of M. Aurel. By 175 $\mathrm{AD}$, series were minted in all metals with the image of the young standing Comodus, holding a branch and a sceptre, behind which there is a trophy with the inscription PRINC IVVENT (Fig. 31) (RIC III: 262, nos. 600-603; 263, nos. 615617; 334, nos. 1518-1522; 335, nos 1527-1529). ${ }^{51}$ This depiction of Comodus closely resembles the motif of Iuventas from the caesarian series of M. Aurel. During the same year and in the following year, aurei and denarii were minted with the inscription PRINCIPI IVVENTVTIS (around) and a picture of an altar bearing the words FORT

49 In 166, M. Aurel proclaimed his sons Comodus and Verus for caesares (Kienast 2010: 140, 147). Verus lived only for seven years (162-169). Already in 175, at the age of 15, Comodus received the toga virilis and the title of princeps iuventutis, and in 177 , he received the title of an augustus and tribunial rights possessed also by M. Aurel himself (SHA, Vita Marcus XXVII.5).

50 According to SHA, M. Aurel was aware that Comodus was not the best solution for inheriting, he had a bad opinion about him and he said to his friends that: »it was hard for him to leave a son (like that) behind « (SHA, Vita Marcus XXVII.11). It remains unclear why he interrupted the tradition of adoption, which already showed as a successfull solution. Ignoring Comodus' character, believing in his good side, the loss of vital interest, belief that his close associates would manage to control and lead the heir, could be some of the reasons for such a decision by M. Aurel (CAH XI: 376).

51 Illustration taken from BMC IV, P1. 66.5. 
REDVCI (Fig. 32) (RIC III: 263, nos. 618, 619). ${ }^{52}$ Fortuna redux appears on coins that are connected to emperors' travels and to their safe return to the capital. ${ }^{53}$ In this particular case, it refers to Marc Aurel's journey to the East at the end of 175 AD in order to settle relationships following the end of Avidius Cassius' rebellion. On this journey, he was accompanied by Faustina and Comodus and therefore, Fortuna redux appears on M. Aurel's mintings (RIC III: 240, nos. 343-345) and on the caesarian series of Comodus..$^{54}$

The inscription EQVESTER ORDO PRINCIPI IVVENT was written in four lines on a shield lying over two spears (RIC III: 336, n. 1534 ) or within an oak wreath (RIC III: 336 , n. 1536). Both of the examples were minted as parts of a series referring to the triumph over the Germans and the Sarmathians, which Marc Aurel celebrated together with his son on the $23^{\text {rd }}$ of December $176 \mathrm{AD}$. At the same time, bronze coins with the inscription PRINCIPI IVVENTVTIS and an image of clasped hands holding an aquila at the bow of a ship were minted for Comodus (RIC III: 337, n. 1548). These types of images or varieties without the bow usually appear with the inscriptions fides militum/exercituum or concordia militum/exercituum and indicate the military vow given or the concordance within the army. ${ }^{55}$

52 Illustration taken from BMC IV, P1. 66.12.

53 It was common for the Romans to express their gratitude to Fortuna Redux, celebrating the emperor's safe return and inviting her to guide them again in good fortune. During the Principate, she first appeared in Augustus' minting from 19 BC. Here the altar of Fortuna Redux, which was erected in Rome during the same year, was depicted on the reverse side (RIC I: 45, nos. 53-56). From Hadrian's time through to the time of Marc Aurel, the image of Felicitas as felheicitati augusti also appears on coins along with a ship, which also symbolises the safe return of the emperor or prince.

54 At the end of the following year, in $176 \mathrm{AD}$, the emperor returned to the capital with his son and this journey was depicted with the image of a ship on both Marc Aurel's (RIC III:307, nos. 1192-1199) and Comodus' mintings (FELICITATI CAES) (RIC III: 307-308, nos. 1200-1201). 55 The image of clasped hands with the inscription CONCORD EXERC appeared on M. Aurel's minting from 175 AD (RIC III: 302, nos. 1122-1125) on the occasion of
The Comodus example was minted after the celebration of the German and Sarmathian triumph, but before his proclamation as an augustus on the 17th of June $177 \mathrm{AD} .{ }^{56} \mathrm{We}$ can presume that it refers to a presentation of the young prince to the army as the future heir and through this, the army is asked to support him and to remain loyal, as it is to his father.

An image on a sestertius minted for Comodus in $175 / 6 \mathrm{AD}$ testifies that Marc Aurel never had any doubts regarding his heir. Along with the inscription IOVI CONSERVATORI, Jupiter is depicted standing and holding a thunderbolt and a sceptre and under the thunderbolt there is the image of Comodus holding a trophy (Fig. 33) (RIC III: 335, nos. 1524, 1525). ${ }^{57}$ The theme was already developed at the time of Traian and Hadrian, but it referred to the current emperor and not to the princep, as it was in the case of Comodus. The image was repeated by Comodus at the beginning of his independent rule, with the difference being that he holds a branch and a sceptre instead of the trophy (RIC III: 403, n. 304). Finally, the image of Castor, like the one on the previously mentioned mintings of Marc Aurel, should be included in the caesarian series of Comodus, indicating his function as princeps iuventutis (RIC III: 340, nos. 1578-1580).

During his independant reign, Comodus continued developing the theme of providentia deorum, a reference to higher authorities. On a medallion first minted in $183 \mathrm{AD}$, Jupiter was depicted sitting on a throne, holding a sceptre and handing over the globe to Comodus who is seen standing in front of him (Fig. 34) (Gnecchi II: 68,

Avidius Cassius' rebellion, who was the regent of Syria. However, the usurper was murdered and the rebellion subdued before it grew into a bigger usurpation (CAH XI: 360-362). The main association of the clasped hands is the vow and Fides, while the inscription indicated concordance within the army. Cf. ref. 38 .

56 The inscription on the obverse is: COMMODO CAES AVG FIL GERM SARM COS.

57 Illustration taken from BMC IV, P1. 85.3. 
n. 146). ${ }^{58}$ Later, in 191/192 AD, he minted denarii and sestertii with the inscription I O M SPONSOR SEC AVG and an image in which he stands, holding the globe and the sceptre, with Jupiter next to him placing his right hand on the emperor's shoulder and holding a thunderbolt (Fig. 35) (RIC III: 396, n. 255; 434, n. 596). ${ }^{59}$ Jupiter first appears as the supreme deity upon whose decision Comodus is proclaimed a ruler and later also as a guarantor of the emperor's security.

The insignificant and scandalous rule of Comodus led to a plot from within the senate and among the praetorians which culminated in his murder. The weak solution of Marc Aurel to stop the system of adoption and to leave the empire to his incapable son led to another civil war. The winner of this war was Septimius Severus, who established a new dynasty and constructed the system of inheriting the throne from within a family. A bigger role in keeping the dynasty on the throne was actually played by the family of his wife Iulia Domna in 235 AD, since Septimius Severus' plan had already failed in the generation that followed its conception.

At the beginning of his rule, Severus minted aurei with an image of Jupiter holding a sceptre and handing over the globe to the emperor, who stands opposite, holding a spear (Fig. 36) (RIC IV.1: 95, n. 35). ${ }^{60}$ After this initial "legitimacy" of the rule of the supreme deity, in 195 AD Septimius Severus began his active dynastic propaganda. He found a formal way to secure continuity and legitimacy of the rule - he adopted himself into the Antonine family by declaring himself divi Marci Pii filius, divi Commodi frater. At the same time, or maybe slightly later, he named his eldest son Bassianus after Marc Aurel, and from that time onwards, he was known as M. Aurelius Antoninus. He also gave him a caesarian title, while Iulia Domna was given the title mater castrorum, previously possessed only by Faustina the younger

58 Illustration taken from Gnecchi II, Tav. 88.1. 59 Illustration taken from BMC IV, P1. 100.3. 60 Illustration taken from RIC IV.1, Pl. 5.12.
(Birley 2002: 116-117; Kienast 2010: 156, 162). Such a proclamation of himself as a son of the deified Marc was noted on bronze coins minted in 195/196 AD, with the inscription DIVI M PII F ..... and with images of Roma or Felicitas (RIC IV.1: 185 , n. $686 ; 187$, n. 700; 188, n. 712). Already, in the spring of $197 \mathrm{AD}$, both sons were entitled princeps iuventutis, and in the following year, Caracalla was entitled augustus whilst Geta was entitled caesar. By proclaiming Caracalla as his co-ruler, Severus followed the example of Marc Aurel, although he often criticised him for not deposing Comodus as an incapable ruler. Nevertheless, the love for his sons pre-empted the care of the state and Severus kept insisting on his offspring as heirs for the rest of his life (Birley 2002: 130, 183). ${ }^{61}$

From 197 to 206 AD, coins in all metals were minted for Caracalla, with the image of the young prince as the leader of the youth, along with the inscription in its full or shortened form. He was depicted in several similar motifs - standing in a military uniform, holding either a club and a spear, a branch and a sceptre or a branch and a spear, while next to him there is a trophy (Fig. 37) (RIC IV.1: 213, n. 13; 218, n. 38A; 233, n. 140; 263 ,n. $329 ; 276$, n. 398). ${ }^{62}$ From 200 to 208 AD, coins made from all metals were also minted for Geta, with the inscription PRINCEPS IVVENTVTIS. Just like his brother, he was depicted in a military uniform with a club or with a branch and a spear next to a trophy (RIC IV.1: 316, nos. 1518; 329, n. 106; 331, n. 113A; 332, n. 125). Apart from these, on coins and medallions, depictions of Septimius, Caracalla and Geta on galloping horses also appear (Fig. 38) (RIC IV.1: 319, n.37; 332 , n. 124; 333, n. 130; Gnecchi II: 78, n. 7). ${ }^{63}$ In Geta's mintings, depictions with the same in-

61 Septimius Severus was aware of the difference in his sons' characters and of their mutual intolerance. He kept trying to make peace among them and to make them cooperate (Herodian 3.13.3-6)

62 Illustration taken from BMC V, Pl. 10.12.

63 Illustration taken from BMC V, Pl. 50.4. 
scription along with five horsemen appeared, two horsemen above galloping to the left and three beneath galloping to the right (RIC IV.1: 333, n. 131). As with earlier examples, in the caesarian series of M. Aurel and Comodus, the depiction of Castor next to a horse was also minted for Geta (RIC IV.1: 315, n. 6).

The dynastic policy of Septimius Severus expressed on coinage was highly developed and represented on many examples and showed all family members. All of this clearly shows his intention first to establish, and then to gain adequate support for, a dynasty, initially from the army, which had already helped him ascend the throne as a usurper. The propaganda exercise was well-conducted, but the choice of the heir was wrong, as would be later proven. During the British campaign, Severus gave the title of augustus to his youngest son (Kienast 2010: 166). The emperor's dying wish was for the brothers to rule together (SHA, Vita Sev. XXII. 3-6). After Severus' death in February 211 AD, Caracalla, just like Comodus before him, made peace with his enemies and started to prepare for his return to Rome. His passionate wish to become an independent ruler became unacceptable after his father's death, because Geta enjoyed the same rights by recently being proclaimed an augsutus. ${ }^{64}$ In December 211 AD, Caracalla organised a meeting with Geta, during which he killed him (CAH XII: 43, Kienast 2010: 166). To justify this, he informed to the Senate and the army that Geta had plotted against him. The Senate had no choice but to accept this story and Caracalla presented huge financial rewards to the army (SHA, Vita Geta 6.1-2). Caracalla possessed a disturbed personality and his physical state was still worsening. Dissatisfaction, resulting in a plot, led to his murder in April $217 \mathrm{AD}$ in Mesopothamy.

64 According to Herodianus, the haterige and intolerance among brothers were so expressed that, after Propontis'es advice, they were supposed to divide the rule of the empire: Caracalla was supposed to rule Europe and Northern Africa and Geta was supposed to rule the Asian provinces and Egypt (CAH XII: 42-43, ref. 1).
The legions in the east called out the praefectus pretoriae Macrinus on the new emperor, who had organised the plot. He immediately faced difficulties, since the women from the Severan family had great influence over the troops in that region, especially in Syria, with their intention being to bring their own offspring to the throne. ${ }^{65}$ Macrinus tried to save his position - he took the name of the Severi for himself, he deified Caracalla, he gave his son the title of Diadumenos princeps iuventutis, he proclaimed him a caesar and later also an augustus by naming him Antoninus. As well as that, he had to present his choice to higher authorities as well, like Jupiter, showing sacral modesty. On the denarii of the first series, a colossal figure of Jupiter, holding a thunderbolt above the very small figure of the emperor figure is presented, with the inscription VOTA PVBLICA (Fig. 39) (RIC IV.2: 6, n. 5). ${ }^{66}$ During his short rule, Macrinus minted quite a large number of different reverse motifs in all metals for his son Diadumenos, with the legend PRINCEPS IVVENTVTIS. ${ }^{67}$ The prince is depicted in a military uniform, standing and holding a stick and a sceptre whilst behind, there are two military insignia (Fig. 40$),{ }^{68}$ or holding another military insignia instead of the stick (Fig. 41) ${ }^{69}$ (RIC IV.2: 13-14, nos. 101-112; 22, nos. 211-217; Gnecchi III: 40, n. 1). In the second example, on top of the military insignia held by the prince, there is a hand symbolising sacramentum - the military vow that had

65 Iulia Domna had great influence while Septimius Severus was still alive and she had numerous titles, but she also thought that she could bring peace among brothers and secure the continuity of the dynasty. After Geta's murder, she accepted the situation and tried to play a positive role during the unfortunate rule of Carcalla. She committed suicide in April 217. The leading role was now overtaken by her sister Iulia Maesa, with her daughter Iulia Soemias (Elagabal's mother) and Iulia Mammaea (Alexander Severus' mother) (CAH XII: 44, 52-53).

66 Illustration taken from BMC V, P1. 78.1.

67 Macrinus ruled from April 217 AD to June 218 AD (Kienast 2010: 169).

68 Illustration taken from BMC V, Pl. 80.16.

69 Illustration taken from BMC V, Pl. 84.4. 
been taken. Such motifs would become a popular way of depicting princes as leaders of the youth and they are encountered until the end of the Principate.

By heavily influencing the Syrian troops, Iulia Maesa managed to get her grandson Elagabalus proclaimed as the next emperor, while Macrinus was defeated and murdered. All the events which lead to the election of Elagabalus showed who was in control of the rule of the state - out of the confusing circumstances and with a shared interest, the army along with the women from the Severan family managed to secure the continuity of the dynasty (CAH XII: 52-53). Still, Elagabalus' election was a bad choice since, as a bizarre personality, he soon caused dissatisfaction. Iulia Maesa took the initiative again and, with the help of the praefectus praetoriae Comazon, began to support the son of her other daughter, Alexander, who was favoured among the soldiers. In March $222 \mathrm{AD}$, Elagabalus and his mother were murdered and Alexander Severus was brought to the throne at the age of 14. The ruling the state was taken over by Iulia Mammea, together with a council consisting of 16 senators, among which there were two of the most respected lawyers. The respect of the senate was returned, and finances and the law were restored. However, the appearance of the new enemy in the east, as well as riots on the Rhine border, together with the inner problems reflected in the dissatisfaction of the army, led to a mutiny by the troops who subsequently murdered Alexander and his mother in $235 \mathrm{AD}$ and proclaimed Maximine the Thracian as the new emperor.

At Iulia Maesa's insistence, in June 221 $\mathrm{AD}$, Elagabalus adopted Alexander and entitled him princeps iuventutis and a caesar (Kienast 2010: 177). Bronze coins were minted for him, as they had been earlier for Diadumenos, with an image of the prince in a military uniform, holding a stick and a sceptre with two military insignia behind (RIC IV.2: 102, n. 386). Later on, during his independent reign, Alexander Severus minted medallions with more developed images, in which he receives the globe from Jupiter. In the middle of the picture there is a military insignia in front of which Jupiter stands with a sceptre. There is the emperor in a military uniform, with a spear, shown handing over the globe. Behind each depiction ofJupiter and the emperor there is a soldier with a military insignia. The accompanying inscription is FELICITATI POPVLI ROMANI (Fig. 42) (Gnecchi II: 80, n. 5). ${ }^{70}$ On another medallion, Jupiter sits on a throne and hands the globe over to Alexander, who stands in front of him in a military uniform and is holding a spear, behind the emperor there are two soldiers; the inscription reads PERPETVITAS IMP AVG (Gnecchi II: 80 , n. 10). In this case, to the more usual scene in which the emperor receives the symbol of global rule from the deity, soldiers and insignia are added, acting as witnesses to this act. The emphasised military aspect, which is also reflected in the emperor's military uniform, separates this motif from the previous ones (Hadrian, Comodus) in which Jupiter "crowns" the toga wearing emperor. Apart from that, for the first time, Jupiter's choice (providentia deorum) was explicitely connected with felicitas populi romani, a concept which is closely connected with permanent renovation and eternity (Fears 1981: 117, ref. 571). Felicitas, as the symbol of true happiness, possessing the most precious gift of fortune telling, brings peace and welfare to the lives of the Roman people.

The plan of the women from the Severan dynasty to establish the interest of the state and the dynasty by supporting the Senate in the state in which regime was already based on military rule was predicted to fail, since they were incapable of ruling over the army. After the death of Alexander Severus, a development phase of the Principate as a system was ended and the era of solder-emperor began, which lasted until Diocletian's time and the tetrarchy. The Principate, as a social system, developed and adjusted from the very beginning

70 Illustration taken from Gnecchi II, Tav. 98.5. 
but did not change its structure from the time of Septimius Severus' rule, who actually legalised the state within the army and its leadership. Whether changes were necessary should be discussed as a separate topic but in any case, the most important consequence was the very big influence of the army on the political life of the state. The change of system itself would not play a decisive role in the weakening of the state, since economic difficulties were also connected with this along with more complex outside dangers. The highly organised and powerful Persian state presented as a serious threat and, additionally, there were constant raids by various tribes along the Rhine and the Danube.

During the aforementioned period, many different rulers sat on the throne, mostly assisted by the army. The Senate no longer had influence on the rule and its role was reduced to accepting the emperor chosen by the army. Origin was also no longer of importance and people of low origin ascended to the throne, typically military leaders who were able to stand up to the outside enemies. They achieved high ranks after the reforms of Septimius Severus, with the equestrian class supporting him, whilst being opposed to the Senate. Each new princeps would proclaim his son or sons as a co-ruler and an augustus. Thus, the chosen model of inheritance was kept within a family. However, only in one case did the son live long enough to succeed his father (Galienus), because most of the principes of this period were murdered, not by their enemies, but by their political opponents. An exception to this was the unexpected initiative by the Senate in $238 \mathrm{AD}$, which aimed to establish the collective rule of two principes - Pupienus and Balbinus. This unique attempt was probably aimed more at resembling the previously existing duality and equality of the highest magistrates of the Republic than the wish of the Senate to establish dual principality as a general rule (CAH XII: 78). ${ }^{71}$

71 A close connection between the new augusti and the
As previously mentioned, from the time of Diadumenos there exists a motif of a prince with the military insignia which would occur, more or less, until the end of the Principate, with the obvious attempt to represent a maximum variety of the details depicted. Princes were depicted in military uniforms with all the appropriate attributes - the stick of a commanding officer, a spear, military insignia, the parasonium of Virtus or a sceptre all of which emphasise the military aspect. In this manner, the caesarian series of Maximus, the son of Maximinus Thrax, shows the prince depicted in a military uniform, standing next to two military insignia, holding a stick and a spear (Fig. 43) (RIC IV.2: 155 , nos. 3,$5 ; 156$, nos. 9-10) or a globe and a spear, with the inscription PRINCIPI IVVENTVTIS (RIC IV.2: 155, n. 4). ${ }^{72}$

The large variety of details in images with the princeps iuventutis motives are shown on caesarian series of Philipp II. ${ }^{73}$ The prince is depicted alone, in a military uniform, holding a globe and a sceptre (RIC IV.3: 95, n. 216) or followed by a soldier holding a spear (Fig. 44) (RIC IV.3: 95, n. 217). ${ }^{74}$ Some examples also show an image in which Philipp II stands, holding a globe and a spear (RIC IV.3: 96, n. 218, 101, nos.255-257) or with an added small figure of a captive at his feet (Fig. 45) (RIC IV.3: 96, n. 219). ${ }^{75}$ The prince is depicted holding a military insignia and a spear (Fig. 46) (RIC IV.3: 96, n. 220; 101, n. 258A) ${ }^{76}$ or a globe and a spear (RIC IV.3: 101, nos. 255-257).

Senate is also visible on reverse images of coins with the inscription PATRES SENATVS (RIC IV.2: 174, n. 11), in keeping with the collegiums of the Twenty.

72 Illustration taken from HCC III, Pl. 55. M.C. 11. Maximus was entitled a caesar and a princeps iuventutis between the 7 th of January and the 16th of May 236 AD (Kienast 2010: 185).

73 Philipp II was proclaimed for a caesar between the $23 \mathrm{rd}$ of July and the 15th of August $244 \mathrm{AD}$, when he was also entitled princeps iuventutis. Three years later (July/August) $247 \mathrm{AD}$, he was proclaimed augustus (Kienast 2010: 200).

74 Illustration taken from RIC IV.3, P1. 8.7.

75 Illustration taken from HCC III, Pl. 74.10.

76 Illustration taken from HCC III, Pl. 74.19. 
The more developed images, with a multitude of details, are depicted on two extraordinary medallions minted for Philipp II, with the inscription PRINCIPI IVVENTVTIS. On the first one, the prince is depicted in the middle of the composition, wearing a military uniform and holding a spear. A soldier on his right side crowns him with a wreath and, in addition, he holds an insignia and a shield. A soldier on the other side also holds an insignia whilst leaning on a shield (Fig. 47) (Gnecchi II: 97, n. 6). ${ }^{77}$ On the second medallion, Philipp II is again depicted in the middle of the scene, wearing a military uniform, with the stick of a commanding officer, and holding a military insignia, with another one in front of him. Behind the prince there is a soldier with a shield and an insignia with a hand on top (Fig. 48) (Gnecchi II: 97, n. 7). ${ }^{78}$

Similar to other solder-emperor, Traian Decius also gave his sons the titles of caesares and princeps iuventutis, first Herenius Etruscus and later, Hostilianus. ${ }^{79}$ On the caesarian series of Herenuis Etruscus, scenes are depicted similar to those on the mintings of Philipp II: the prince is wearing a military uniform, holding a stick and a spear (RIC IV.3: 139, n. 147; 143, n. 171) or holding a military insignia and a spear (RIC IV.3: 139, n. 148; 140, n. 153A; 143, n. 172). As a completely new motif, with the legend PRINC IVVENT/ VTIS, there is a depiction of a seated Apollo, holding a branch and leaning his elbow on a lyre (Fig. 49) (RIC IV.3: 139, nos. 144-146; 140, n.

77 Illustration taken from Gnecchi II, Tav. 108.7. 78 Illustration taken from Gnecchi II, Tav. 108.8.

79 Herenius Etruscus was proclaimed a caesar at the end of May or at the beginning of June $250 \mathrm{AD}$, while he was entitled augustus in June 251 AD. Hostilianus was proclaimed as a caesar in September 250 AD. He was entitled augustus after the death of his father and his brother (June 251 AD), who were killed by the heir Trebonianus Gallus, proclaimed as the new emperor by the army. At the same time, Trebonianus Gallus entitled his son Volusianus a caesar and a princeps iuventutis. Hostilianus soon died and Volusianus was proclaimed augustus in August of the same year (Kienast 2010: 206-210).
153). ${ }^{80}$ This is the image of Apollo salutaris who takes care of the prince's health, in whose hands the future of the state lies. For the younger Hostilianus, coins were minted with similar depictions: the prince is wearing a military uniform, holding an insignia and a spear (RIC IV.3: 144, nos. 181$182 ; 149$, n. 216); or holding a stick and a spear, the motif which also appears on a medallion (RIC IV.3: 144, n. 183; 149, n. 217; Gnecchi II: 102, n. 1 ); or standing in front of two insignia, touching the closer one, while he holds a spear in the other hand (RIC IV.3: 149, n. 218). In the caesarian series of Hostilianus, the example with Apollo repeats (RIC IV.3: 144, n. 180; 149, nos. 214, 215), and it appears again, with the same inscription, in his augustan series (RIC IV.3: 145, n. 189; 150, n. 219).

For Volusianus, coins were minted with the inscription PRINCEPS IVVENTVTIS in the caesarian, as well as the augustan series. We again encounter the same motifs: the prince wearing a military uniform, holding a stick and a spear (RIC IV.3: 173, n.129; 174, nos. 130, 134; 179, n. 183; 187, n. 241; 179); holding an insignia and a spear (RIC IV.3: 177, n. 159) or holding a globe and a sceptre (RIC IV.3: 187, n. 242). Gallienus minted a great number of examples for his sons with the same, or similar, motifs. ${ }^{81}$ Valerianus II was depicted in a military uniform, holding a stick and a spear next to two insignia (RIC V.1: 116, n. 5; 121-122, nos. 44, 51); holding a military insignia and a spear (RIC V.1: 117, n. 11); holding a globe and a spear (RIC V.1: 118, n. 23; 120, n. 39); holding a military insignia and a sceptre (RICV.1: 119 , n. $29 ; 120$, nos. $34,37,38,40$ ); or holding a spear and a shield and crowning a trophy (RIC V.1: 121-122, nos. 45, 49, 50). In the caesarian series of coins and medallions of Saloninus, there

80 Illustration taken from HCC III, P1. 80.12.

81 Galienus was proclaimed a caesar in September/October $253 \mathrm{AD}$ and immediately afterwards (before the 22nd of October $253 \mathrm{AD}$ ) as an augustus. In $258 \mathrm{AD}$, he himself entitled Valerianus II and Saloninus caesares and princeps iuventutis (Kienast 2010: 218, 221). 
is probably the largest number of different motifs with the princeps iuventutis theme. The prince is depicted, just like the emperors before him, wearing a military uniform, with a stick, a spear, military insignia, or sceptre or standing next to a trophy (RIC V.1: 123-126, nos. 3, 5, 10-12, 18-20, 27, 30; Gnecchi III: 61-62, nos. 15, 20). As princeps iuventutis, Saloninus appears on coins and medallions in a scene in which he holds a globe and a sceptre and, next to his feet, there is a small figure of a captive (Fig. 50) (RIC V.1: 127, nos. 32-34; Gnecchi II: 111, n. 3). ${ }^{82}$ In addition, Saloninus, Maximus, Philipp II and Volusianus were also depicted with a globe, an attribute usually reserved for the emperor himself,rather than for a prince. The legend of Amalteia and Jupiter was used again, after Domitianus, in the mintings of Valerianus II. Along with the inscriptions IOVI CRESCENTI and IOVI EXORIENTI, there is a boy-Jupiter riding a goat (RIC V.1: 116, n. 1; 119, n. 32). Coins were also minted for Saloninus, with the motive of Jupiter handing Victoria over to the prince, with the inscription DII NVTRITORES (RIC V.1: 127, n. 35). These last three examples are connected with the renovatio temporum and aeternitas themes, with growth and education aimed at representing the princes as a substitute for Jupiter on earth.

Just as earlier, in Volusianus', Carinus' and Numerianus' caesarian and augustan series, the inscription PRINCEPS IVVENTVTIS appears together with the previously mentioned motifs (RIC V.2: 156, nos. 147, 150; 158, nos. 158-160; 160, nos. 181-186; 172, n. 267; 188, nos. 360-366; 196, nos. 417-421). Similar pairings - the legend and the depiction of princeps iuventutis in the augustan series - are encountered with Galienus', Florian's, Probus' and Carus' mintings and with the mintings of Tetricus I. They were represented holding a globe and a spear, a globe and a sceptre, a military insignia and a spear or an insignia and a vexil-

82 Illustration taken from Gnecchi II, Tav. 116.5. lum. ${ }^{83}$ For the people of the time, this image most likely represented only an allusion to the close connection with the equestrian class (RIC V.2: 3).

During the reign of the so-called solderemperor, as previously described, universal moti usually appear, stressing the military aspect of the princes' role. During these turbulent times, filled with serious internal and external problems which were permanently destroying the internal system, it is only natural that this happened. The heirs to the throne had to be represented as military commanders who would, one day, be capable of standing up as a leader against the external enemy. Starting with the republican meaning of the princeps iuventutis title as the leader of the equestrian class, and then on to Octavianus, who used it for the first time as a way of representing the heir to the throne then, until the time of the solder-emperor, it had always had a certain military aspect. However, from the initial idea of Octavianus to represent the heirs as future statesmen and military leaders (Gaius and Lucius were represented dressed in togas, with shields and spears), during the $3^{\text {rd }}$ century it was reduced to only the second of these aspects. The feeling of insecurity during the $3^{\text {rd }}$ century's crises was depicted through the images of providentia deorum. Ever since the time of Gordianus III and especially during the times of Aurelianus, Probus and Carus, images appeared in which the emperor receives a globe as a symbol of global rule, not only from Jupiter, but also from Roma, Concordia, Solus, Mars, a soldier or, as in the case of Carinus and Numerianus, from their fathers. ${ }^{84}$ It seems that ever since the time of

83 Galienus (RIC V.1: 70, n. 26; 154, n. 265); Florianus (RIC V.1: 357, nos. 79-81); Probus (RIC V.2: 50, n. 318; 115, n. 892); Carus (RIC V.2: 142, n. 61; Gnecchi III: 73, n. 8); Tetricus I (RIC V.2: 410, nos. 114, 115).

84 On coins and medallions of Gordianus III, he is depicted wearing a toga, receiving a globe from Roma sitting on a shield; in the background there is a soldier with an insignia, while the emperor is accompanied by Virtus (RIC IV.3: 48, n. 296; Gnecchi II, 90: nos. 30,31, Tav. 105.2,3). On another medallion, the young emperor is depicted receiving a globe from Solus, whilst being crowned by Victoria as the captives sit next to his feet. Behind Solus there 
Gordianus III, the initial meaning of the image of providentia deorum is slowly lost - as the image of the legitimacy of the rule which was given by the supreme deity himself. It seems that within the scenes of the handing over of the globe, the focus is on the emperor in the function of rector orbis, rather than in seeking legitimacy of the rule. In such a way, motifs appear in which the emperor receives the globe from different deities, either as personifications or as real persons, combined with a multitude of inscriptions which were supposed to explain the idea of the whole composition to the users. In this sense, the globe appears only as an attribute of the ruler of the earth or as a secondary element within a composition, marking, for example a victory, or referring to problems within the army etc. ${ }^{85}$

is a soldier and in the background there are military insignia; the inscription reads VIRTVS AVG (Gnecchi II, 93, n. 56, Tav. 106.8). The first of these examples was minted before the Persian campaign, while the second one, minted during the campaign, already shows signs of victory. In addition, Gordianus III is depicted in Traian's tradition, under the protection of Jupiter's thunderbolt with the inscription IOVI CONSERVATORI (RIC IV.3: 15, n. 2). The combination of this image and the legend appears for the last time in Emilian's mintings (RIC IV.3: 194, n. 4). The inscription IOVI CONSERVATORI also appeared later with motifs in which the emperor receives a globe from Jupiter: Galienus (RIC V.1: 103, n. 440), Aurelianus (RIC V.1: 270, n. 48), Probus (RIC V.2: 59, nos. 385-387). However, on the minting of Probus, Carus and his sons, the image in which the emperor receives the globe from Jupiter is accompanied by the inscriptions CLEMENTIA TEMP and VIRTVS AVGG (RIC V.2: 86, nos. 643-648 (Probus); RIC V.2: 149, n. 118; 150, n. 124 (Carus); RIC V.2: 163-164, nos. 202, 206 (Carinus); RIC V.2: 190-191, nos. 372, 376 (Numerianus). Aurelianus is depicted receiving a globe from Solus, with the inscriptions: ORIENS AVG, SOLI INVICTO, VIRTVS AVG or SOLI CONSERVATORI (RIC V.1: 297, n. 282; 300, nos. 312, 316; 305, n. 353). Additionally, Aureliaus also receives a globe from Concordia with the inscription CONCORDIA MILITVM (RIC V.1: 292, n. 245). Aurelianus and Probus also receive a globe from soldiers, the first with the inscription FIDES MILITVM and the second with RESTITVTOR EXERCITI (RIC V.1: 279, n. 127; RIC V.2: 117, n. 909). Probus receives a globe from Mars, whilst being crowned by Victoria, in the background there is a soldier and two insignia (RIC V.2: 33, n. 146).

85 Fears' opinion is that military metaphors together with Jupiter's investiture of the emperor (having their begin-
The period of solder-emperor lasted for almost fifty years, during which the general crisis deepened and reached its peak during the reigns of Valerianus I and Galienus (253-268). After that, there was a short stabilising period under Aurelianus and Probus, ending with Diocletian's ascension to the throne in $284 \mathrm{AD}$, when a new system of reign was introduced - the tetrarchy. In such a system, an emperor was elected by the army, taking another augustus as his co-ruler, after which both of them chose an additional two caesares. After twenty years, the augusti were supposed to abdicate, which is what happened with Diocletianus and Maximianus in 305 AD. The plan was that they should be inherited by the caesares (Galerius and Constantius), who would be given the title of augusti and would choose their own caesares (Maximinus Daia and Flavius Valerius Severus). The system, however, did not survive and during the following generation, the system of inheritance of the throne within a family prevailed again. Problems occurred in 306 AD, after Constantius' death, since Diocletian's plan excluded the sons Constantius and Maximianus (Constantine and Maxentius) from the reign, a plan with which they did not agree. After lengthly and exhausting conflicts, which lasted until 324 $\mathrm{AD}$, Constantine became the only ruler, a title that was to be inherited by his sons.

The inheritance the throne during the Prin-

nings on medallions of Alexander Severus) were best presentated in the numismatic propaganda during Aurelianus' time. At the beginning of Aurelianus' rule, mints throughout the Empire issued types on which the investiture of the emperor by Jupiter was celebrated, with the inscription IOVI CONSERVATORI, FIDES MILITVM and CONCORDIA MILITVM. Later in his paper, Fears states that, although Solus dominates in the minting from the last years of Aurelianus' reign, this should not be understood as an attempt to suppress the cult of Jupiter. He concludes that Jupiter, as the supreme deity, after making the present situation possible (by positioning Aurelianus for his representative on earth), withdraws and rules the world through his representatives - Solus and Aurelianus, i.e. Oriens Augusti (Fears 1981: 117-118). In this case, the meaning of the motifs, in which Aurelianus receives the globe from Concordia or from a soldier, remains unclear (cf. ref. 85). 
cipate played an important role in the political ambitions of most of the emperors and, in accordance with that, it formed a part of the imperial propaganda at all levels. During the time of Octavian, a republican, the election of functions was still common in Roman society. Although the changes which took place during the civil wars in the $1^{\text {st }}$ century $\mathrm{BC}$ opened the way to a monarchistic system of rule, there were still many opponents to the new regime. For 58 years, Octavian increasingly influenced the political life of the Roman state. ${ }^{86}$ The system of Principate, introduced by him, did not represent a new concept, but a change to the existing one and its adjustment to a new era, an alternative to the traditional social structure ${ }^{87}$ He himself wrote in the Res Gestae that his power arose from taking care of the res publica, illustrated by the ending of the civil war and the handing over of rule to the Senate and the Roman people (Res Gestae 34). Still, he was given the status of the first citizen by the Senate and the people, which also meant that he became the first "servant" of the state. The specific historical circumstances, which lasted for almost a century, strengthened Octavian and, in such circumstances, he later reinforced his position, influencing the necessary transformation of the system as was expected of him. ${ }^{88}$ Just as sought solutions for the

86 Ever since $44 \mathrm{AD}$, the day after Caesar was murdered and his will was opened, according to which he adopted Octavianus and proclaimed him his heir.

87 During the 1st century BC there was a one-way destruction of all of the foundations of Roman society which led it into a serious crisis and, at the same time, there was an obvious incapability to find a way out of the difficulties. This crisis led to the rise of many powerful individuals. These included Pompeius, Caesar, M. Antonius, Octavianus. The Senate tried to stand up to them and their growing influence, which led to a series of civil wars in which the Republic was finally destroyed. It was clear that the system of rule was no longer functioning correctly, but there was no social or political force which could offer an alternative and persist with its insistence to introduce constitutional changes (Meier 1993: 54-55).

88 In contrast to his predecessors, who offered no solutions, by acting directly within the political system and openly facing the Senate, Octavianus managed to effect significant changes within the Roman social structure. He newly established system, Octavian also tried to find a right to inheritance. Finding of an appropriate heir became more and more necessary for him, while on the other side, the "republican program" transformed into the Principate and stood opposed to the principle of inheritance. This represented a serious problem which had to be solved and a way had to be found whereby the position created for the "saviour of the republic" could be handed over to an heir from the same family. A potential heir could not refer to the restoration of the republic, as Augustus did. His position of the first citizen, with all the honours and authorities, was given to him by the Senate and the Roman people, so he tried to create the same consensus for his heir. The family members, potential candidates, were, through the years, gradually introduced to public and military life. They were given authority, admissions and honours for their merits. The political elite and the public were acquainted with these persons and their merits and, in addition to this, the Senate also gave them certain powers by issuing decrees so that, after Augustus' death, it was difficult to refuse such a person. It seems that in such a way, Res publica chose the princeps itself (Eder 1993: 120).

After Tiberius, this practice seemed natural, so inheritance within the Claudian family continued, with the gradual introduction of the praetorians as a factor playing a specific role during the election of a princeps. The dictatorial way in which the praetorians pushed their decisions concerning principes led to dissatisfaction among the provincial legions and, following the unfortunate reign of Nero, there was another civil war. The reasons for this lay within the ever growing role of the army as a political force, rivalries among its various parts, the political ambitions of the lead-

created a system which was deeply rooted in Roman society and, in such a way, after a century of crisis, he demonstrated a clear alternative to the traditional order (Meier 1993: 55-56). After the exhausting civil wars, there was great economic hardship among the citizens and they all wished for but one thing - peace (Rostovtzeff 1926: 30, 39). 
ers as well as in the dissatisfaction with the rule of the last Iulian-Claudian emperor. The winner in the civil war was Vespasianus, who attempted to establish a dynasty. This proved to be a bad solution, since Domitianus was not a suitable candidate for a princeps, a fact that eventually led to his murder. Adoption, which had begun in Nerva's time, emerged as the best solution. The interruption of this practice by Marc Aurel and the handing over the rule to his incapable son again led to dissatisfaction followed by another civil war. Inevitably, this was also accompanied by other difficulties (of an economic nature, as well as external dangers) which together, were the first signs of the crisis of the $3^{\text {rd }}$ century. Septimius Severus repeated Marc Aurel's mistake and left the throne to his sons, although, owing to the great influence of the Severan women, the dynasty managed to survive until 235 AD. The rule of Septimius Severus represents a breaking point in the re-modelling of the Principate, which would, in its final phase at the end of the $3^{\text {rd }}$ century, evolve into the Dominate. Severus was an intruder but chosen as emperor by the army, who supported him during his entire rule and with whom he was more or less forced to cooperate in order to oppose the Senate and a large section of the provincial aristocracy. As a consequence of the legal and financial favour that it enjoyed, the army grew too strong, making the state dependant on its decisions. Following this, there was the era of the so-called solder-emperor, during which several dozen emperors, mostly of low origin, ascended the throne, brought to power by the army.

In other words, there was no rule of inheritance of throne during the Principate. Usually, an emperor would recommend an heir during his lifetime, either from his family or an adopted individual. Father-to-son inheritance proved less successful and often led to civil wars and murders, since such rulers were often incapable. Adoption, which was practiced from Nerva's time through to Marc Aurel's time, was found to be a better solu- tion. Whoever the incumbent emperor chose, he would try, by all means necessary, to present the heir to the army and the people in a favourable light. Principes were introduced into pubic life, they were given certain jurisdictions and titles, followed the emperor on his travels and military campaigns and had coins minted for them with appropriate images depicted. An important segment of the official propaganda was occupied by the motifs of princeps iuventutis and, later, also by motifs which expressed the providentia of the supreme deity or the emperor himself. The chosen heirs also appeared on reverse images of incumbant emperors, accompanying them on platforms during the distribution of gifts to the people (liberalitas/congiarium), during addresses to the army (adlocutio) and in triumphal scenes. They were also depicted with their patron deities etc. Regardless of the personal choice of the actual princeps, whether he chose a family member or an adopted son, these decisions should not be considered separately from the socio-economic circumstances of the first three centuries which, together, decided the destiny of the Principate. 


\section{BIBIOGRAPHY}

Арсенијевић, М. 2006.

Војнички аспект Фидес и Конкордије у римском царском ковању (I-III в.). Гласник САД 22: 63-110.

Birley, A. R. 2002

Septimius Severus, The African Emperor, London and New York: Routledge.

\section{BMC I - V 1923-1950}

Coins of the Roman Empire in the British Museum, London: British Museum Trustees.

\section{CAH X-XII. 1971-1976}

The Cambridge Ancient History, Cambridge: University Press.

\section{Clark, M. E. 1983}

Spes in the Early Imperial Cult: „The Hope of Augustus“, Numen, Vol. 30, Fasc. 1: 80-105.

\section{Dio Cassius, 1927}

Historia Romana. Dio's Roman History, Vol. VIII, Books 61-70, Loeb Classical Library, Translated by E. Cary, Cambridge Mass.-London: Harvard University Press.

\section{Eder, W. 1993}

Augustus and the Power of Tradition: The Augustan Principate as Binding Link Between Republic and Empire, in Between Republic and Empire, Interpretations of Augustus and His Principate, ed. by Kurt A. Raaflaub and Mark Toher, 71-122, Los Angeles-London: University of California Press.

\section{Fears, J. R. 1981}

The Cult of Jupiter and Roman Imperial Ideology, in Aufstieg und Niedergang der Römischen Welt II.17.1, 3-141, Berlin: Gruyter.

\section{Gnecchi, F. 1912}

I Medaglioni Romani, Vol. II, Bronzo, Bologna: Forni Editore.

\section{Grant, M. 1954}

Roman Imperial Money, Edingurgh: Nelson and sons LTD.

\section{HCC III 1977}

Roman Imperial Coins in the Hunter Coin Cabinet III, London-Glasgow-New York: Oxford University Press.

\section{Herodian of Antioch 1969}

History of the Roman Empire, Vol. I, Loeb Classical Library No. 454, translation C. R. Whittaker, Cambridge Mass.-London: Harvard University Press.

\section{Kienast, D. 2010}

Römische Kaisertabelle, 4. Auflage, Darmstadt: WBG.

\section{LIMC VII 1994}

Lexicon Iconographicum Mythologiae Classicae, Zürich und München: Artemis\&Winker Verlag.

\section{Macdonald, D. 1979}

Observations on an Augustan Coin Type, Jahrbuch für Numismatik und Geldgeschichte 28/29 (1978/1979) (1979): 27-29.

\section{Meier, C. 1993}

C. Caesar Divi filius and the Formation of the Alternative in Rome, in Between Republic and Empire, Interpretations of Augustus and His Principate, ed. by Kurt A. Raaflaub and Mark Toher, 54-70, Los Angeles-London: University of California Press.

\section{OCD. 1979}

The Oxford Classical Dictionary, Ed. by N. G. L. Hammond and H. H. Scullard, Oxford: Clarendon Press. 
Preimesberger, R. 2011

Paragons and Paragone, Los Angeles: Getty Research Institute.

Ranieri, de C. 2001

Salus, Felicitas, Fortuna: Le virtutes di un imperatore Romano. Analisi di alcune monete Commodiane, Rivista italiana di numismatica CII: 167-191.

$\mathrm{RE}=$ Paulys Real-encyclopädie der Classischen Altertumswissenschaft.

\section{Res Gestae 1924}

Velleius Paterculus and Res Gestae Divi Augusti, Translated by Frederick W. Shipley, Loeb Classical Library, Cambridge Mass., London: Harvard University Press.

\section{RIC I - V.2. 1933-1984}

The Roman Imperial Coinage, London: Spink \& Son, LTD.

\section{SHA 1921-1932.}

The Scriptores Historiae Augustae. Vol. I-III. Translated by David Magie, Loeb Classical Library, Cambridge Mass., London: Harvard University Press.

\section{Stevenson, S. W. 1964}

A Dictionary of Roman Coins, London: B. A. Seaby LTD.

\section{Strack, P. L. 1933}

Untersuchungen zur Römischen Reichsprägung des zweiten Jahrhunderts, Teil 2: Die Reichsprägung zur Zeit des Hadrian, Stuttgart: W. Kohlhammer.

Svetoni, C. Tranquilli 1978.

Dvanaest rimskih careva. Prevod Stjepan Hosu. Rijeka: Naprijed.
Tacitus, Publius Cornelius 1970.

Анали. Превод Љиљана Црепајац. Београд: Српска књижевна задруга.

Tacitus, Publius Cornelius 1987

Historije. Prevod Josip Miklić, Zagreb: VPA.

\section{REZIME}

NASEĐIVANJE PRESTOLA TOKOM PRINCIPATA U SVETLU REVERSNIH PREDSTAVA NA RIMSKOM CARSKOM NOVCU

\section{KLJUČNE REČI: PRINCIPAT, NASLEĐIVANJE, PRIKAZI NA REVERSU, PRINCEPS IUVENTUTIS.}

Dinastička politika tokom Principata predstavljala je važan segment oficijelne propagande ostvarivane putem novca. Osnovni način bilo je dodeljivanje titule princeps iuventutis izabranom kandidatu, od strane aktualnog princepsa. Ovo je bila titula poštovana još od republikanskih vremena, davana je mladiću koji povede starije i mlađe dečake određene da odigraju ulogu u igri Troje (ad ludum Troiae). Princeps iuventutis bio je u Republici vođa konjaničkog staleža, a njegova glavna obeležja bila su koplje i srebrni štit. Od vremena Avgusta ova titula počinje da se dodeljuje mlađim, muškim članovima carske porodice, budućim naslednicima prestola. Princeps iuventutis dobijao je srebrni štit i koplje, a predstave na novcu pratile su, na odgovarajući način, taj važan čin u životu budućeg vladara. Prinčevi su se od mladosti pripremali i obučavali za ulogu koja ih očekuje, zauzimali su važne državne i vojne funkcije. Različite predstave na novcu pratile su legendu PRINCEPS IVVENTVTIS, a sve u cilju da se građanima i vojsci predstavi izabrani naslednik, i da se prikaže kao kvalifikovan i sposoban budući vladar.

Naseđivanje prestola tokom Principata zauzimalo je važno mesto u političkim ambicijama većine careva, a skladno sa tim činilo je 
i deo carske propagande na svim nivoima. U vreme Oktavijana, rimskom društvu još uvek je bilo blisko, republikansko, izborno preuzimanje funkicja u državi. Mada su promene do kojih je došlo tokom građanskih ratova u I v.s.e. otvorile put monarhističkom jednovalašću, još uvek je bilo dosta protivnika novog režima. Tokom 58 godina Oktavijan je kontinuirano vršio stalno narastajući uticaj u političkom životu rimske države. Sistem Principata koji je uveo nije predstavljao novu koncepciju, već promenu postojećeg i njegovo prilagođavanje novom vremenu, jednu alternativu tradicionalnom poretku. Specifične istorijske okolnosti koje su trajale skoro jedan vek, koje su iznedrile Oktavijana i u kojima je on potom izgradio svoj položaj, umnogome su uticale na transformacije u sistemu koje su bile i nužne a i očekivane. Kao što je tražio rešenja za novonastali sistem, Oktavijan je pokušavao da nađe i pravo za nasleđivanje. Pronalaženje adekvatnog naslednika postajalo je za njega postepeno sve nužnije, sa druge strane u Principat preoblikovani „republikanski program“ bio je u suprotnosti sa principom nasleđivanja. Ovo je predstavljalo realnu poteškoću koju je trebalo razrešiti i pronaći način kako poziciju koja je bila izgrađena po meri za „spasioca Republike“ preneti na naslednika iz kruga porodice. Potencijalni naslednik nije mogao da se poziva na restauraciju Republike, kao što je to činio Avgust. Svoj položaj prvog građanina, sve počasti i ovlašćenja, dobio je od Senata i rimskog naroda, te je na isti način pokušao da ostvari konsenzus i za naslednika. Članovi porodice, potencijalni kandidati, godinama su postepeno uvođeni u društveni i vojni život, dobijali su ovlašćenja, priznanja i počasti za svoje zasluge. Politička elita i javnost su bile sa ovim ličnostima i njihovim zaslugama upoznate, osim toga Senat im je sam svojm dekretima dodeljivao ovlašćenja, te bi bilo teško da, nakon smrti Avgusta, odbiju takvu osobu. Čini se da je na ovaj način Res publica sama izabrala sledećeg princepsa.

Nakon Tiberija, ova praksa činila se prirod- nom, te je nastavljeno sa nasleđivanjem u okviru porodice Klaudijevaca, uz postepeno uključivanje pretorijanaca kao faktora prilikom izbora princepsa. Svojevrsna diktatura pretorijanaca u nametanju odluka po pitanju princepsa dovela je do nezadovoljstva među provincijskim legijama, te je nakon nesrećne Neronove vladavine došlo do ponovnog izbijanja građanskog rata. Razlozi ovog sukoba ležali su u narastajućoj ulozi vojske kao političkog činioca, rivaliteta između njenih pojedinih delova, političkim ambicijama lidera, kao i nezadovoljstvu vladavinom poslednjeg predstavnika dinastije Julijevaca-Klaudijevaca. Kao pobednik iz građanskog rata izašao je Vespazijan koji je ponovo pokušao sa formiranjem dinastije. Ovo se pokazalo kao loše rešenje, jer Domicijan nije bio odgovarajuća ličnost za položaj princepsa, što je na kraju dovelo do njegovog ubistva. Adopcija, sa kojom je započeto od Nerve, pokazala se kao najsrećnije rešenje. Prekidanje ove prakse od strane Marka Aurelija i prenošenje vlasti na nesposobnog sina, ponovo je dovelo do nezadovoljstva i izbijanja građanskog rata. Ovome su naravno dopirinele i druge poteškoće (ekonomske prirode kao i spoljna opasnost) koje su zajedno najavljivale dolazeću krizu ispoljenu tokom III veka. Septimije Sever je ponovio grešku Marka Aurelija i vlast ostavio sinovima, mada se je dinastija Severa zahvaljujući uticaju žena iz ove porodice održala na vlasti do 235.g. Vladavina Septimija Severa predstavalja, prelaz i prelomni momenat u daljem remodelovanju Principata, koja će u konačnoj fazi dovesti do prelaska u Dominat krajem III veka. Sever je na vlast došao kao uzurpator, izabran od strane vojske, na čiju podršku se oslanjao tokom cele svoje vladavnine, na šta je uglavnom bio prinuđen zaradi opozicije od strane Senata i velikog dela provincijske aristokratije. Kao posledica favorizovanja vojske u legalnom i materijalnom smislu, dolazi do njenog preteranog jačanja i stvaranja zavisnosti države od njenih odluka. Nakon toga nastupio je period tzv.“vojničkih careva" u kojem se je na vlasti izmenjalo više de- 
setina careva, uglavnom niskog porekla, koje je na vlast dovodila vojska.

Pravila u nasleđivanju prestola, dakle, tokom Principata nije bilo. Uglavnom je car za života preporučio naslednika, bilo da je bio iz kruga porodice, bilo da je adoptiran. Nasleđivanje sa oca na sina se pokazalo manje uspešnim i uglavnom je vodilo u građanske ratove i ubistva, jer se obično radilo o nesposobnim vladarima. Adopcija, koja je sprovođena od Nerve do Marka Aurelija kontinuirano, pokazala se kao bolje rešenje. Bilo koji izbor da je učinio aktuelni car, trudio se potom da svim dostupnim sredstvima predstavi naslednika vojsci i građanima. Prinčevi su uključivani u javni život, dobijali su različite titule i ovlašćenja, pratili cara na putovanjima i vojnim pohodima, za njih je kovan novac sa primerenim predstavama. Važan segment oficijelne propagande pripadao je predstavama sa motivima princeps iuventutis, a potom i motivima koji su izražavali providentia vrhovnog božanstva ili aktuelnog cara. Izabrani naslednici pojavljivali su se i na reversnim predstavama aktuelnih careva, u njihovoj pratnji na platformi prilikom podela učinjenih narodu (liberalitas/congiarium), prilikom obraćanja vojsci (adlocutio), u scenama trijumfa, prikazivani su sa božanstvima svojim zaštitnicima, itd. Nezavisno od ličnog izbora aktuelnog princepsa, bilo da se odlučio za člana porodice ili adopciju, ove odluke se ne smeju posmatrati odvojeno od društvenoistorijskih okolnosti tokom prva tri veka koje su ukuno krojile sudbinu Principata. 
Vojvoda, Tapavički-Ilić - Inheriting the Throne...(303-328) Archaeology and Science 7 (2011)
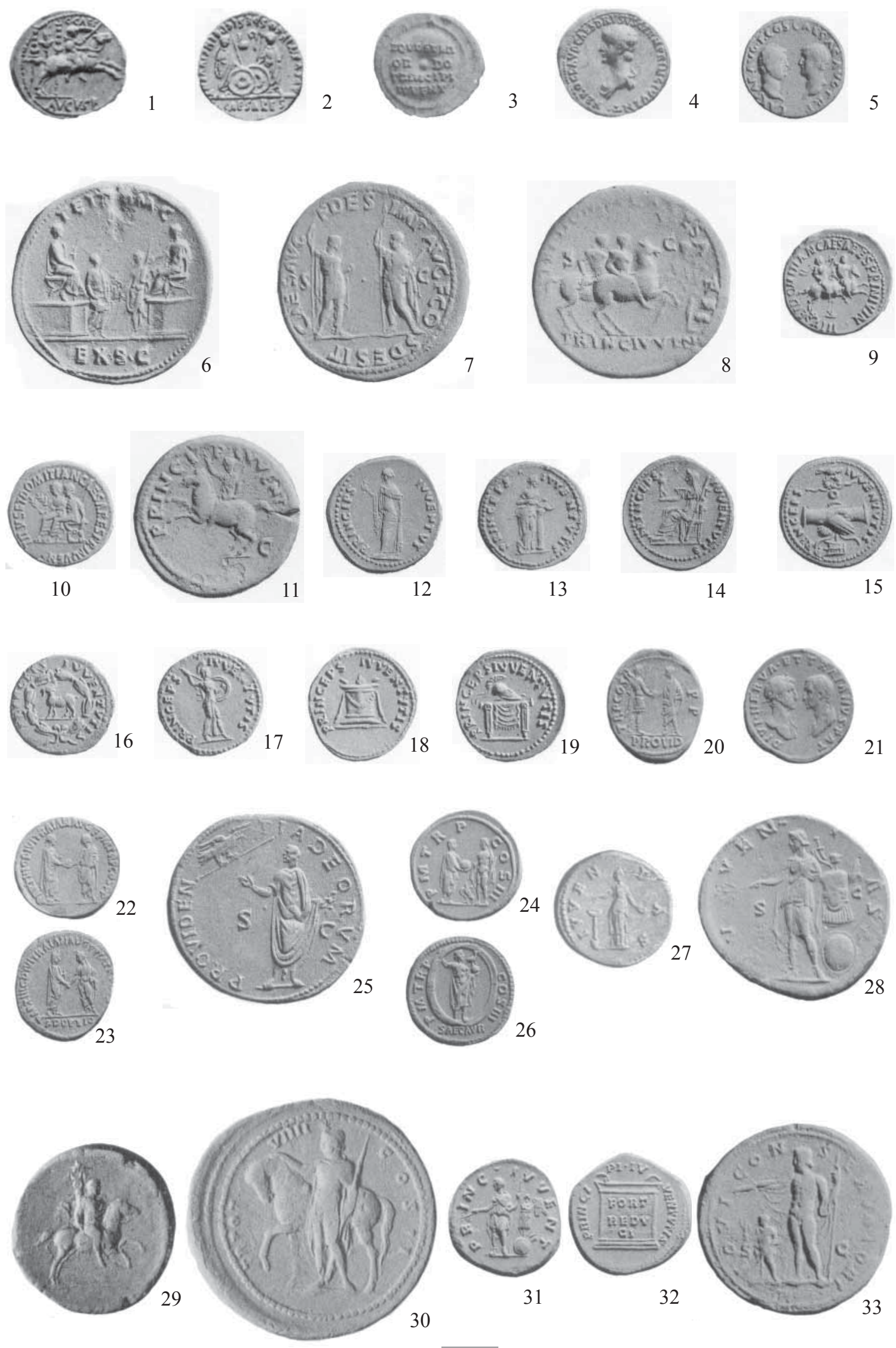
Archaeology and Science 7 (2011) Vojvoda, Tapavički-Ilić - Inheriting the Throne... (303-328)
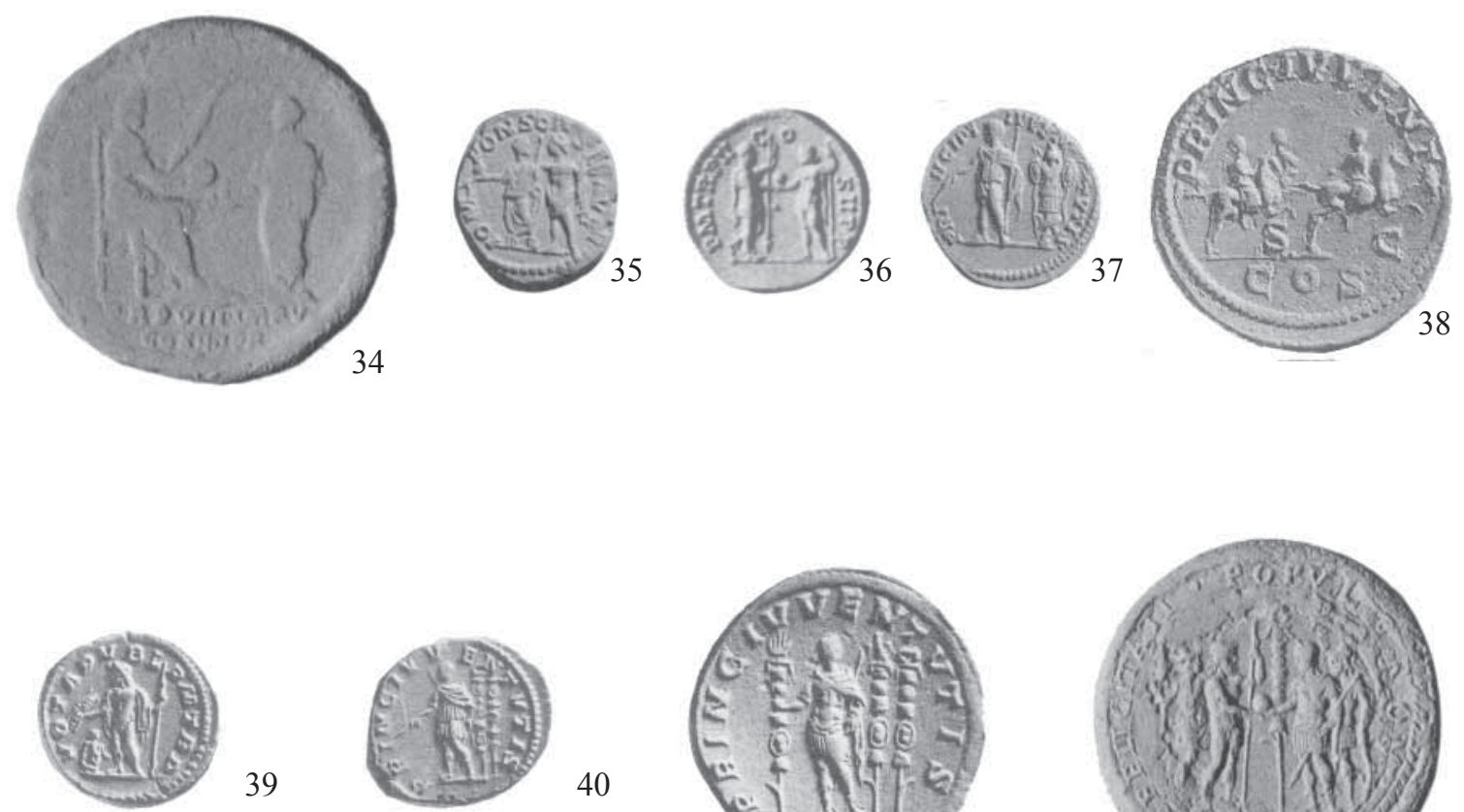

39

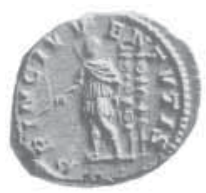

40
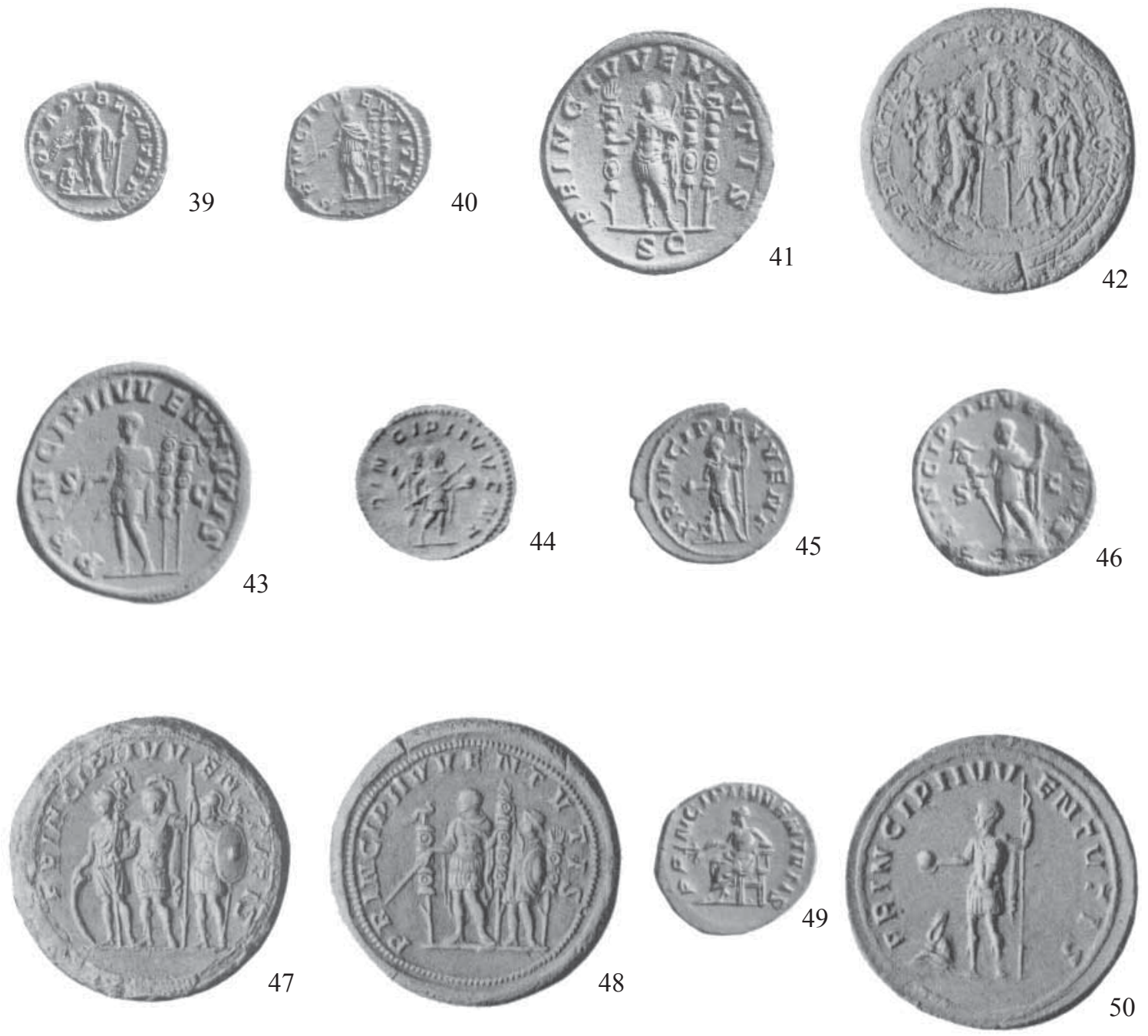